\title{
Cetacean occurrence in the Gulf of Alaska from long-term passive acoustic monitoring
}

\author{
Ally Rice ${ }^{1}\left[\begin{array}{l}\text { D } \\ \text { Ana Širović }\end{array}{ }^{1,2} \cdot\right.$ Jennifer S. Trickey ${ }^{1} \cdot$ Amanda J. Debich $^{1,3} \cdot$ Rachel S. Gottlieb $^{1} \cdot$ Sean M. Wiggins ${ }^{1}$. \\ John A. Hildebrand ${ }^{1} \cdot$ Simone Baumann-Pickering ${ }^{1}$
}

Received: 23 November 2020 / Accepted: 11 April 2021 / Published online: 24 April 2021

(c) The Author(s) 2021

\begin{abstract}
The Gulf of Alaska is an important habitat for a diverse array of marine mammals, many of which were severely depleted by historical whaling. To study current cetacean distributions in this region, passive acoustic monitoring was used to detect species-specific call types between 2011 and 2015 at five locations spanning the continental shelf, slope, and offshore seamounts. Spatial and temporal detection patterns were examined for nine species to compare differences in behavior and habitat use. Mysticetes showed seasonal increases in calling that indicated possible behavioral shifts between feeding and breeding in blue (Balaenoptera musculus), fin (B. physalus), and humpback (Megaptera novaeangliae) whales, and matched known migration timing of gray whales (Eschrichtius robustus). Interannual changes in blue and fin whale calling may relate to the marine heat wave that began in 2013 and lasted through the end of the monitoring period. Odontocete detections revealed unique spatial distributions, with killer whales (Orcinus orca) most common on the continental shelf and sperm whales (Physeter macrocephalus) most common on the continental slope, where detections occurred year-round. Beaked whales showed both spatial and temporal separation: Baird's beaked whale (Berardius bairdii) detections were highest at Quinn Seamount in the spring, Cuvier's (Ziphius cavirostris) at Pratt Seamount in winter, and Stejneger's (Mesoplodon stejnegeri) on the continental slope in the fall. The year-round presence of many species highlights the ecological importance of the Gulf of Alaska and the spatiotemporal information reported here should inform future conservation efforts.
\end{abstract}

\section{Introduction}

The Gulf of Alaska (GoA) is a North Pacific region composed of a variety of habitats (a shallow continental shelf region, a steep shelf break, deep offshore waters, and deepwater seamounts), all of which are important to a diverse array of marine mammal species. This region is considered a highly productive marine ecosystem due to its subarctic

Responsible Editor: D. Crocker.

Reviewers: undisclosed experts.

Ally Rice

arice@ucsd.edu

1 Scripps Institution of Oceanography, University of California San Diego, La Jolla, CA 92093, USA

2 Texas A\&M University At Galveston, 200 Seawolf Parkway, Galveston, TX 77554, USA

3 Rosenstiel School for Marine and Atmospheric Science, Cooperative Institute for Marine and Atmospheric Studies, University of Miami, Miami, FL 33149, USA climate and the presence of upwelling that is linked to the Alaska Current and Alaska Coastal Current (Stabeno et al. 2004). Historical whaling records (Danner et al. 2006; Ivashchenko et al. 2014; Rocha et al. 2014) and more recent surveys (Consiglieri et al. 1982; Brueggeman et al. 1987, 1988; Mellinger et al. 2004a, 2004b; Zerbini et al. 2006; Stafford et al. 2007; Rone et al. 2017) indicate that the GoA is utilized by both mysticetes and odontocetes, with very different life histories and habitat requirements.

Many of the mysticetes found in this region were severely depleted by historic commercial whaling (Danner et al. 2006; Rocha et al. 2014). Blue whales (Balaenoptera musculus) are currently considered endangered under the Endangered Species Act (ESA) and have only occasionally been sighted in the GoA in recent years (Zerbini et al. 2006; Calambokidis et al. 2009; Rone et al. 2017), but passive acoustic monitoring efforts indicate that blue whales from both the Northeast Pacific (NEP) and Central/Western Pacific (CWP) populations inhabit this region for at least a portion of the year (Stafford et al. 2001, 2007; Stafford 2003; Zerbini et al. 2006; Rone et al. 2017). 
Fin whales (B. physalus) are also currently considered endangered under the ESA, and of the three humpback whale (Megaptera novaeangliae) distinct population segments that inhabit the GoA for at least a portion of the year, one is considered threatened and another is listed as endangered (NOAA 2016). Sightings of both fin and humpback whales are typically highest during summer (Consiglieri et al. 1982; Brueggeman et al. 1987; Mizroch et al. 2009), while acoustic detections of these two species peak during winter (Stafford et al. 2007). Both of these species prey on krill and small schooling fish (Nemoto and Kawamura 1977; Witteveen 2008). High concentrations of fin and humpback whales are found around Kodiak Island, indicating the region's importance for foraging (Consiglieri et al. 1982; Brueggeman et al. 1987, 1988; Waite et al. 1999; Zerbini et al. 2006; Stafford et al. 2007; Ferguson et al. 2015; Rone et al. 2017).

There are two gray whale (Eschrichtius robustus) stocks in the North Pacific that can be found in the GoA: the western North Pacific stock is considered endangered under the ESA, while the eastern North Pacific stock has recovered to its estimated pre-whaling population size (NMFS 1994; Rocha et al. 2014). Seasonal increases in sightings of gray whales in the spring and fall (Consiglieri et al. 1982; Brueggeman et al. 1987) coincide with their known spring-time migration north to feed in the Bering and Chukchi Seas in summer and fall-time migration south towards breeding grounds in Mexican waters for the winter. However, winter sightings of gray whales around Kodiak Island (Moore et al. 2007) may indicate that the GoA is of additional biological significance to gray whales beyond its use as a migration corridor (Ferguson et al. 2015).

For the critically endangered North Pacific right whale (Eubalaena japonica), the current minimum population estimate is only 26 individuals (Wade et al. 2011b). Due to their low population size, sightings of North Pacific right whales are very rare in the GoA, with only six sightings from 1966 to 2006, all occurring south of Kodiak Island (Zerbini et al. 2006; Wade et al. 2011a). Acoustic detections of this species, while also rare, have occurred in areas farther offshore where there have not been visual sightings (Mellinger et al. 2004b; Širović et al. 2015a).

Sperm whales (Physeter macrocephalus) were also heavily targeted by commercial whaling, which severely depleted their population in the North Pacific (Whitehead 2002; Rocha et al. 2014; Ivashchenko and Clapham 2015). However, sperm whales have been documented in the GoA year-round, with higher acoustic detections in summer likely related to movement of some individuals into the area for feeding (Mellinger et al. 2004a; Diogou et al. 2019). Worldwide, sperm whales feed primarily on cephalopods and some demersal and mesopelagic fish (Kawakami 1980; Clarke et al. 1993; Evans and Hindell 2004), but in the GoA, they rely more heavily on fish than elsewhere and are known to depredate longlines (Okutani and Nemoto 1964; Kawakami 1980; Straley et al. 2014; Wild et al. 2020).

Even killer whales, which were not a target of whaling, have varying conservation statuses. There are three killer whale (Orcinus orca) ecotypes in the GoA: residents, transients, and offshores, defined by genetic, morphological, and behavioral differences (Ford 1991; Ford et al. 1998; Hoelzel et al. 1998; Barrett-Lennard 2000; Deecke et al. 2005; Dahlheim et al. 2008). Of the three known resident stocks in the area, the southern residents are critically endangered under the ESA and the northern residents are listed as threatened under the Canadian Species at Risk Act (SARA). Of the three known transient stocks in the area, one is considered depleted under the Marine Mammal Protection Act and another is listed as threatened under the SARA (Muto et al. 2019). In the GoA, sightings of killer whales are most common along the continental shelf and slope (Consiglieri et al. 1982; Brueggeman et al. 1987; Zerbini et al. 2007; Rone et al. 2017).

Finally, Baird's (Berardius bairdii), Cuvier's (Ziphius cavirostris), and Stejneger's (Mesoplodon stejnegeri) beaked whales have all been found in the GoA, primarily in deep offshore waters (Brueggeman et al. 1987; Rone et al. 2017). However, sightings of all beaked whale species are rare and their presence and distribution in the GoA have mostly been inferred from stranding data (Mitchell 1968; Loughlin and Perez 1985; Walker and Hanson 1999). As a result, abundance estimates do not exist for these species, and the status of beaked whales in the GoA is not well understood (Consiglieri et al. 1982; Barlow et al. 2005; Muto et al. 2019).

The unknown status, but year-round presence, of many of these cetacean species in the GoA warrants continued monitoring, particularly as populations recover from whaling and face changing oceanographic conditions. These are both factors that may influence current and future distributions of these species, either due to increased competition for resources as populations grow (Straley et al. 2018), or from changes in prey availability as ocean temperatures increase (Davis et al. 2020), and decades-old studies cannot necessarily be relied upon to represent current distributions. In 2013, the GoA experienced a marine heatwave that increased sea surface temperatures and lasted into 2015 (Bond et al. 2015). Ecological events set off by this heatwave are still being studied (Whitney 2015; Cavole et al. 2016; Pena et al. 2019). Passive acoustic studies are an efficient method for conducting year-round monitoring of ecologically important regions for the many species to which acoustic signals have been definitively attributed, and is particularly effective in pelagic regions that have not been heavily surveyed.

The five mysticete species examined in this study all produce low-frequency call types that can be reliably identified by trained analysts or automatic detection algorithms. Blue whale calls recorded in the GoA include tonal calls 
produced by two different populations: NEP (B call) and CWP (Central Pacific (CenPac) call; Stafford 2003). These calls are low frequency $(<20 \mathrm{~Hz})$, have a long duration, are often regularly repeated, and are possibly associated with reproduction (McDonald et al. 2006; Oleson et al. 2007a). Another call type commonly produced by blue whales worldwide is the D call (Thompson et al. 1996; McDonald et al. 2001; Mellinger and Clark 2003; Rankin et al. 2005). These calls are downsweeps that last several seconds and are considered a social call, possibly associated with feeding (Oleson et al. 2007a; Lewis et al. 2018). Fin whales produce two types of short (approximately 1-s duration), low-frequency calls called 20-Hz (Watkins 1981) and 40-Hz calls (Watkins 1981; Širović et al. 2013). Humpback whales produce both song and non-song calls, typically ranging from 100 to $3000 \mathrm{~Hz}$ (Payne and McVay 1971; Thompson et al. 1986; Dunlop et al. 2007; Stimpert et al. 2011; Fournet et al. 2015). Song has been reported on Alaskan feeding grounds from August to November (McSweeney et al. 1989; Gabriele and Frankel 2002). The most dominant nonsong call types are known as growls and whups, which are low-frequency (peak frequency $<150 \mathrm{~Hz}$ ), short-duration (1 s or less), and often quiet calls, especially relative to displays of song (Wild and Gabriele 2014; Fournet et al. 2015, 2018b). Gray whales produce a variety of calls described as creaks, moans, and grunts (Crane and Lashkari 1996). The call produced most often by migrating gray whales is the M3 call-a low-frequency, short moan with most energy around $50 \mathrm{~Hz}$ (Crane and Lashkari 1996). North Pacific right whales make a variety of sounds, including tonal signals such as upcalls and downcalls, as well as broad-band signals such as gunshots (McDonald and Moore 2002; Crance et al. 2017). Although the gunshot is the predominant signal type reported for North Pacific right whales (Crance et al. 2017), the upcall has been used commonly for passive acoustic studies because it is believed to be produced by both sexes (Clark 1982; McDonald and Moore 2002). The 1-s upcall typically sweeps from about 90 to $150 \mathrm{~Hz}$, or as high as $200 \mathrm{~Hz}$ (McDonald and Moore 2002).

The five odontocetes investigated in this study produce high-frequency impulsive echolocation clicks, and some also produce frequency-modulated whistles or pulsed calls. Sperm whales produce various types of echolocation clicks known as regular clicks, creaks, slow clicks, and codas (Watkins and Schevill 1977; Goold and Jones 1995; Madsen et al. 2002; Watwood et al. 2006). These clicks typically contain energy from 2 to $20 \mathrm{kHz}$, with the majority of energy between 10 and $15 \mathrm{kHz}$ (Møhl et al. 2003). Killer whale clicks are broad-band, impulsive signals that can have energy up to $85 \mathrm{kHz}$ and often occur in a series when used for echolocation (Ford 1989). Killer whales also produce whistles, which are tonal calls that have varying durations and frequencies, but typically occur from 5 to $10 \mathrm{kHz}$, and pulsed calls, which sound tonal but are a rapid series of pulses that have peak energy between 1 and $6 \mathrm{kHz}$ (Ford 1989; Thomsen et al. 2001). The three killer whale ecotypes have distinct repertoires of pulsed calls (Ford 1991; BarrettLennard et al. 1996; Yurk et al. 2002; Deecke et al. 2005; Saulitis et al. 2005; Sharpe et al. 2017) as well as different vocalization rates for these different signal types (Heise et al. 1993; Barrett-Lennard et al. 1996; Deecke et al. 2005). Killer whales also produce a type of whistle known as a high-frequency-modulated (HFM) signal, which is an ultrasonic tonal that ranges up to $36 \mathrm{kHz}$ in the North Pacific, where this signal has only been attributed to the offshore ecotype (Samarra et al. 2010; Filatova et al. 2012; Simonis et al. 2012; Gassmann et al. 2013). Beaked whales produce an echolocation pulse with a polycyclic structure and a characteristic frequency-modulated (FM) upsweep (BaumannPickering et al. 2013a). The unique peak frequency, spectral peaks, and inter-pulse intervals of these signals are used to discriminate between different species (Johnson et al. 2004; Zimmer et al. 2005; Baumann-Pickering et al. 2013a, b, c). Unlike other beaked whales in the area, Baird's beaked whales often incorporate whistles and burst pulses into their acoustic repertoire (Dawson et al. 1998).

Using species-specific call types, the aim of this study was to examine the spatial and temporal distribution of five mysticete and five odontocete species in the GoA within a long-term passive acoustic dataset at five recording sites monitored from 2011 to 2015. This sort of long-term, yearround monitoring is required to understand species' presence in the GoA and to anticipate how distributions may shift in response to variables such as changing oceanographic conditions and population levels. Continuous, long-term acoustic monitoring of the GoA has been primarily focused on blue, fin, humpback, and sperm whales at offshore recording locations (Mellinger et al. 2004a; Stafford et al. 2007; Diogou et al. 2019) where visual surveys have been rare until recent years (Rone et al. 2017). By examining an array of nearshore and offshore habitats and identifying multiple call types for a species when possible, we were able to document year-round spatiotemporal distributions in the GoA. Since many of the species we examined are currently considered endangered or data deficient (Muto et al. 2019), the information provided here can inform future conservation efforts in this region.

\section{Methods}

\section{Data collection}

Passive acoustic monitoring was conducted at five sites in the GoA (Fig. 1) using High-frequency Acoustic Recording Packages (HARPs; Wiggins and Hildebrand 2007). HARPs were placed on the seafloor with a calibrated hydrophone, 


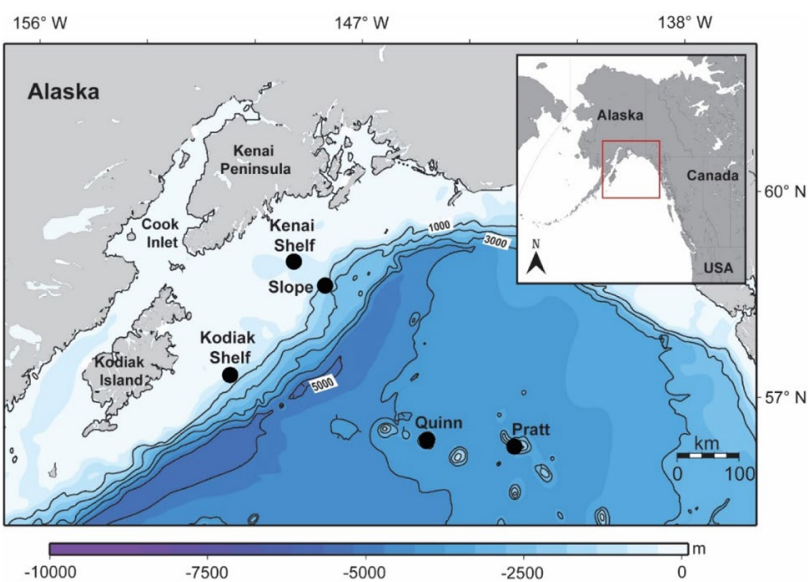

Fig. 1 Map of the Gulf of Alaska showing the locations of Highfrequency Acoustic Recording Package (HARP) deployments (black circles) from July 2011 to September 2015; Kenai Shelf: Kenai Peninsula shelf site, Kodiak Shelf: Kodiak Island shelf site, Slope: continental slope site, Quinn: Quinn Seamount site, Pratt: Pratt Seamount site. Colorbar shows depth in meters. The red box in the inset map of northwest USA and Canada indicates the study site. Map generated using Maptool, a product of seaturtle.org

which had a nominal sensitivity of $-202 \mathrm{~dB}$ re $1 \mathrm{Vrms} / \mu \mathrm{Pa}$ from $10 \mathrm{~Hz}$ to $100 \mathrm{kHz}$, suspended $10-30 \mathrm{~m}$ above (Wiggins and Hildebrand 2007). There were 21 deployments where sampling was continuous and 2 where a duty cycle was used (Table 1). Duty cycled deployments recorded for $10 \mathrm{~min}$ on and $2 \mathrm{~min}$ off. Additionally, 21 deployments had a sampling rate of $200 \mathrm{kHz}$ and 2 deployments had a sampling rate of $320 \mathrm{kHz}$ (Table 1). The five sites included two shallow continental shelf sites: one offshore Kenai Peninsula (Kenai Shelf, $200 \mathrm{~m}$ depth) and the other offshore Kodiak Island (Kodiak Shelf, $\sim 230 \mathrm{~m}$ depth), a continental slope site in deep water off Kenai Peninsula (Slope, 850-1000 m depth), and two deep offshore sites: Quinn Seamount (Quinn, 930 m depth) and Pratt Seamount (Pratt, 980 m depth). These sites were monitored intermittently from July 2011 to September 2015 (Fig. 2; Table 1). There were 3,764 days of recording effort overall (Table 1). Slope had the highest number of days with recording $(1,309)$, while Kodiak Shelf had the lowest (386).

\section{Terminology}

A variety of methods were used to identify cetacean calls in this dataset. Hereafter, the term "detection" will only be used when generally referring to identified calls and will be further qualified when used to refer to calls identified using a specific methodology (Kowarski and Moors-Murphy 2020). Calls that were identified by human analysts will be referred to as "manual detections," while calls that were identified by a computer algorithm will be referred to as "automatic detections." For cases where calls were automatically detected and then each detection was verified by a human analyst, results will be referred to as "manually validated detections."

\section{Call detection}

For analysis of blue, fin, gray, and North Pacific right whales, acoustic data were decimated by a factor of 100 , creating data with a bandwidth up to $1 \mathrm{kHz}(1.6 \mathrm{kHz}$ for deployments that sampled at $320 \mathrm{kHz}$ ), allowing more effective scanning. Humpback whale calls and killer whale whistles and pulsed calls were analyzed from data decimated by a factor of 20, creating data with a bandwidth up to $5 \mathrm{kHz}$ ( $8 \mathrm{kHz}$ for deployments that sampled at $320 \mathrm{kHz}$ ). Full bandwidth recordings were used for analysis of all other species and call types. Species-specific signals were detected either manually using Triton, custom MATLAB (MathWorks, Natick, MA) software, to visually scan long-term spectral averages (LTSAs) in species-specific frequency bands (Wiggins and Hildebrand 2007), or using automatic detection algorithms. For some signals (i.e., blue whale B calls and fin whale $20-\mathrm{Hz}$ calls), detection method varied by site and deployment. Details of these analyses are described below and references for all signal types can be found in Table S1.

Blue whale B, CenPac, and D calls, fin whale $20-\mathrm{Hz}$ and $40-\mathrm{Hz}$ calls, gray whale M3 calls, and North Pacific right whale upcalls were detected manually by scanning 1-h LTSAs with 5-s time and 1-Hz frequency resolution for hourly call presence. When a potential call was found, a 60-s spectrogram (1500-point fast Fourier transform (FFT) length, $90 \%$ overlap) was examined to confirm presence of the call. The number of hours with call presence each day was summed and averaged over weekly and monthly bins.

Out of the 23 deployments, blue whale B calls and fin whale $20-\mathrm{Hz}$ calls were detected automatically using computer algorithms for 12 and 17 deployments, respectively (Table 1). The decision to use manual or automatic detection methods was made per deployment and depended on factors such as data quality and call abundance. For example, deployments at shallow sites (i.e., Kenai Shelf and Kodiak Shelf; Table 1) experienced noise from tidal flow (i.e., strong tidal currents produced flow noise as well as strumming of the hydrophone cable at these sites). To analyze affected data, we opted for manual methods instead of using automatic detectors that would not perform optimally during periods of noise.

Automatic detection of blue whale B calls was performed using spectrogram correlation (Mellinger and Clark 2000; Širović et al. 2015b) as described by Širović et al. (2015b). The performance of this automatic detector is affected by seasonal and interannual shifts in call frequency (McDonald et al. 2009), as well as seasonal changes in call abundance 
Table 1 Details of high-frequency acoustic recording package deployments including: site name, latitude, longitude, depth, sampling frequency, recording duty cycle (on/off durations with "cont."

\begin{tabular}{|c|c|c|c|c|c|c|c|}
\hline Site & Latitude $(\mathrm{N})$ & Longitude (W) & Depth (m) & $\begin{array}{l}\text { Sample rate } \\
(\mathrm{kHz})\end{array}$ & $\begin{array}{l}\text { Duty cycle } \\
\text { (min on/off) }\end{array}$ & Analysis period & Effort days \\
\hline \multirow[t]{6}{*}{ Kenai shelf } & $59^{\circ} 00.51^{\prime}$ & $148^{\circ} 54.49^{\prime}$ & 202 & 200 & Cont & $7 / 13 / 2011-8 / 31 / 2011$ & 19 \\
\hline & $59^{\circ} 00.41^{\prime}$ & $148^{\circ} 54.46^{\prime}$ & 203 & 200 & $10 / 2$ & $5 / 3 / 2012-4 / 11 / 2013$ & 343 \\
\hline & $59^{\circ} 00.66^{\prime}$ & $148^{\circ} 54.25^{\prime}$ & 200 & 320 & Cont & 6/6/2013-6/17/2013 & 11 \\
\hline & $59^{\circ} 00.61^{\prime}$ & $148^{\circ} 53.96^{\prime}$ & 203 & 200 & Cont & $9 / 6 / 2013-4 / 28 / 2014$ & 235 \\
\hline & $59^{\circ} 00.50^{\prime}$ & $148^{\circ} 54.10^{\prime}$ & 201 & 200 & Cont & 4/29/2014-9/9/2014 & 133 \\
\hline & Total & & & & & & 741 \\
\hline \multirow[t]{4}{*}{ Kodiak shelf } & $57^{\circ} 20.18^{\prime}$ & $150^{\circ} 41.75^{\prime}$ & 234 & 200 & Cont & $6 / 9 / 2013-6 / 27 / 2013^{b}$ & 18 \\
\hline & $57^{\circ} 20.14^{\prime}$ & $150^{\circ} 41.99^{\prime}$ & 230 & 200 & Cont & $9 / 8 / 2013-5 / 1 / 2014^{a, b}$ & 235 \\
\hline & $57^{\circ} 20.00^{\prime}$ & $150^{\circ} 40.07^{\prime}$ & 232 & 200 & Cont & $5 / 1 / 2014-9 / 11 / 2014$ & 133 \\
\hline & Total & & & & & & 386 \\
\hline \multirow[t]{8}{*}{ Slope } & $58^{\circ} 38.74^{\prime}$ & $148^{\circ} 04.13^{\prime}$ & 1000 & 200 & Cont & $7 / 13 / 2011-2 / 19 / 2012^{b}$ & 222 \\
\hline & $58^{\circ} 40.28^{\prime}$ & $148^{\circ} 01.25^{\prime}$ & 900 & 200 & $10 / 2$ & $5 / 3 / 2012-2 / 12 / 2013^{\mathrm{b}}$ & 286 \\
\hline & $58^{\circ} 40.41^{\prime}$ & $148^{\circ} 00.55^{\prime}$ & 877 & 200 & Cont & $6 / 6 / 2013-9 / 5 / 2013^{\mathrm{b}}$ & 90 \\
\hline & $58^{\circ} 40.31^{\prime}$ & $148^{\circ} 01.31^{\prime}$ & 858 & 200 & Cont & $9 / 5 / 2013-4 / 28 / 2014^{\mathrm{a}, \mathrm{b}}$ & 236 \\
\hline & $58^{\circ} 40.26^{\prime}$ & $148^{\circ} 01.43^{\prime}$ & 914 & 200 & Cont & $4 / 29 / 2014-9 / 9 / 2014^{a, b}$ & 133 \\
\hline & $58^{\circ} 40.25^{\prime}$ & $148^{\circ} 01.46^{\prime}$ & 900 & 200 & Cont & $9 / 9 / 2014-5 / 1 / 2015^{a, b}$ & 234 \\
\hline & $58^{\circ} 39.32^{\prime}$ & $148^{\circ} 05.48^{\prime}$ & 929 & 200 & Cont & $5 / 1 / 2015-9 / 6 / 2015^{\mathrm{b}}$ & 108 \\
\hline & Total & & & & & & 1309 \\
\hline \multirow[t]{5}{*}{ Quinn } & $56^{\circ} 20.34^{\prime}$ & $145^{\circ} 11.18^{\prime}$ & 930 & 320 & Cont & $6 / 10 / 2013-9 / 11 / 2013^{a, b}$ & 93 \\
\hline & $56^{\circ} 20.36^{\prime}$ & $145^{\circ} 11.24^{\prime}$ & 930 & 200 & Cont & $9 / 11 / 2013-4 / 16 / 2014^{a, b}$ & 217 \\
\hline & $56^{\circ} 20.48^{\prime}$ & $145^{\circ} 10.99^{\prime}$ & 900 & 200 & Cont & $9 / 10 / 2014-5 / 2 / 2015^{a, b}$ & 233 \\
\hline & $56^{\circ} 20.44^{\prime}$ & $145^{\circ} 11.11^{\prime}$ & 994 & 200 & Cont & $5 / 2 / 2015-8 / 18 / 2015^{\mathrm{b}}$ & 108 \\
\hline & Total & & & & & & 651 \\
\hline \multirow[t]{6}{*}{ Pratt } & $56^{\circ} 14.61^{\prime}$ & $142^{\circ} 45.44^{\prime}$ & 989 & 200 & Cont & $9 / 9 / 2012-6 / 10 / 2013^{a, b}$ & 275 \\
\hline & $56^{\circ} 14.64^{\prime}$ & $142^{\circ} 45.43^{\prime}$ & 987 & 200 & Cont & $6 / 11 / 2013-8 / 20 / 2013^{a, b}$ & 70 \\
\hline & $56^{\circ} 14.58^{\prime}$ & $142^{\circ} 45.41^{\prime}$ & 988 & 200 & Cont & $9 / 3 / 2013-3 / 21 / 2014^{\mathrm{a}, \mathrm{b}}$ & 199 \\
\hline & $56^{\circ} 14.60^{\prime}$ & $142^{\circ} 45.46^{\prime}$ & 987 & 200 & Cont & $4 / 30 / 2014-9 / 10 / 2014^{\mathrm{a}, \mathrm{b}}$ & 133 \\
\hline & Total & & & & & & 677 \\
\hline & Total all sites & & & & & & 3764 \\
\hline
\end{tabular}

${ }^{a}$ Deployment where blue whale B calls were automatically detected

${ }^{\mathrm{b}}$ Deployment where fin whale $20-\mathrm{Hz}$ calls were automatically detected

(Širović 2016). To account for these changes, and to keep rates of missed and false calls as constant as possible, multiple kernels and thresholds were used for each year and site (Tables S2 and S3). Overall, the average precision and recall of the detector was above $80 \%$ (Table S2). Use of this detector allowed for the automatic detection of individual B calls, and they are summed as daily call totals averaged over weekly and monthly bins.

Automatic detection of fin whale $20-\mathrm{Hz}$ calls was performed using an energy detection method (Širović et al. 2004; Nieukirk et al. 2012). This method uses a difference in acoustic energy between signal and noise calculated from the LTSA. The frequency at $22 \mathrm{~Hz}$ was used as the signal frequency (Nieukirk et al. 2012; Širović et al. 2015b), while noise was calculated as the average energy between 10 and denoting continuous recordings), time periods analyzed for this study, and the total number of days with recording effort 


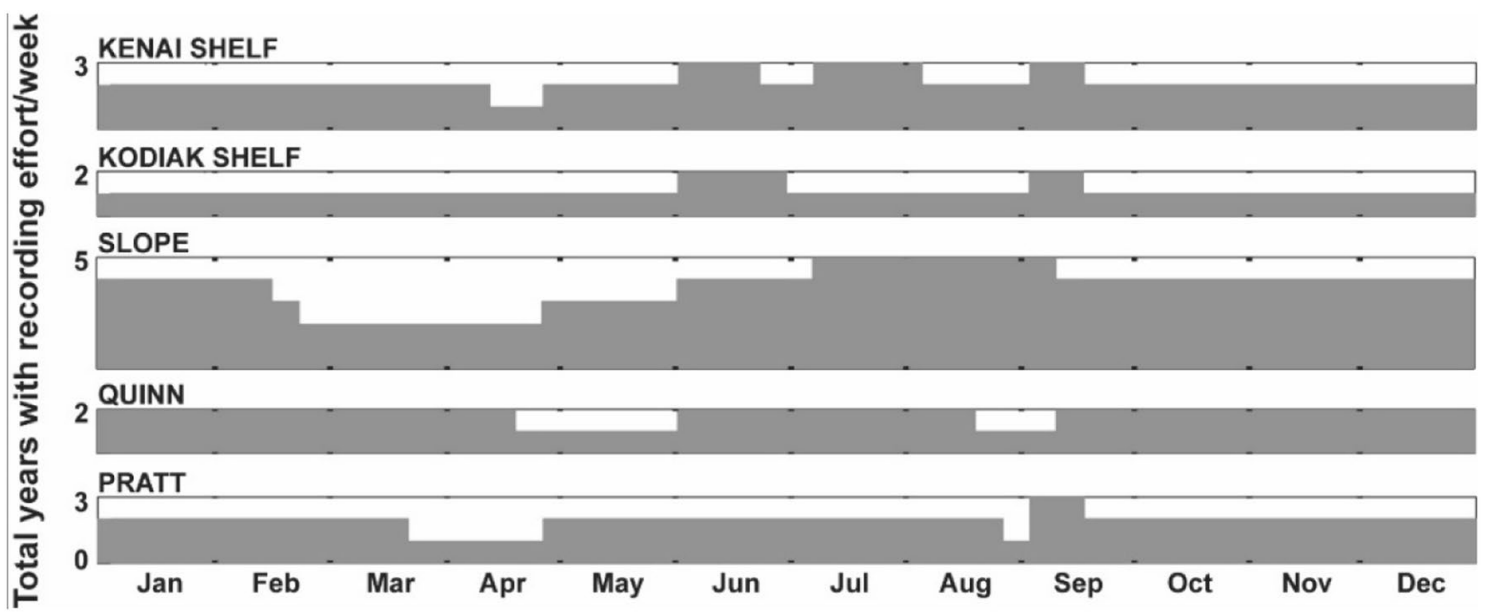

Fig. 2 The total number of years with recording effort (gray bars) during each week at each site. The weekly bins shown are the same as used in the data analysis and indicate how many years of data were averaged for a given week. Kenai Shelf: Kenai Peninsula shelf site with data during 2011-2014, Kodiak Shelf: Kodiak Island shelf

Humpback whale calls were automatically detected using an algorithm based on a generalized power law (Helble et al. 2012). This detector can detect the wide range of humpback whale vocalizations (including both song and non-song call types) across different regions and noise conditions, while keeping missed and false detection rates below 5\% (Helble et al. 2012; Rekdahl et al. 2017; Henderson et al. 2018; Zeh et al. 2020). All automatic detections were verified by a trained analyst using spectrograms that ranged $0.35-3 \mathrm{~s}$ in duration and $0-2,000 \mathrm{~Hz}$ in frequency (these windows could be modified if necessary for call verification), and any false detections were removed.

Most odontocete encounters were manually detected by visual scanning of hourly LTSAs. Killer whale whistles and pulsed calls were manually detected from LTSAs created using a 5-s time average and a $10-\mathrm{Hz}$ frequency resolution. When a potential killer whale call was identified in the LTSA, a 30-s spectrogram (1000-point FFT length, 65\% overlap) was examined to confirm the call.

Sperm whale, Baird's beaked whale, and killer whale clicks, as well as killer whale HFM signals, were manually detected from LTSAs created using a 5-s time average and a $100-\mathrm{Hz}$ frequency resolution. When a potential speciesspecific signal was found, a 5-s spectrogram (1000-point FFT length, $0 \%$ overlap) was examined to confirm presence of the call.

Cuvier's and Stejneger's beaked whale FM pulses were automatically detected using a multistep process that has previously been tested in the Pacific (Baumann-Pickering et al. 2013a, 2014, 2016). First, a Teager-Kaiser energy detector was used to identify all echolocation signals (Soldevilla et al. 2008; Roch et al. 2011). Next, an expert system site with data during 2013-2014, Slope: continental slope site with data during 2011-2015, Quinn: Quinn Seamount site with data during 2013-2015, and Pratt: Pratt Seamount site with data during 20122014. Small differences in effort among species are shown in Figure S1

automatically discriminated between delphinid clicks and beaked whale FM pulses (Roch et al. 2011; BaumannPickering et al. 2013a) using automatic detections within a 75-s segment. Only segments with more than seven automatic detections were used in further analysis. All echolocation signals with a peak and center frequency below 32 and $25 \mathrm{kHz}$, respectively, a duration less than $355 \mu$ s, and a sweep rate of less than $23 \mathrm{kHz} / \mathrm{ms}$ were deleted. If more than $13 \%$ of all initial automatically detected echolocation signals remained after applying these criteria, the segment was classified to have beaked whale FM pulses. These thresholds were chosen to obtain the best balance between missed and false automatic detections. Finally, a classification step based on computer assisted manual decisions by a trained analyst, was used to label the automatically detected segments to pulse type and reject false detections (BaumannPickering et al. 2013a). The rate of missed segments was approximately 5\% (Baumann-Pickering et al. 2013a, 2014). There was no effort to run this detector at the two continental shelf sites, as they were too shallow for the typical habitat of beaked whales.

\section{Propagation modeling}

Loud, low-frequency sounds can propagate over long distances. Therefore, to meaningfully compare detections across different sites, it is necessary to determine how the detection areas differ across those sites (Helble et al. 2013). The methodology used to determine these detection areas was the same as used by Širović et al. (2015b), though some parameters were adjusted based on our study area and call types. In brief, we modeled transmission loss (TL) using the 
Effects of Sound on the Marine Environment (ESME) 2012 Workbench framework (D. Mountain, Boston University; http://esme.bu.edu) and sound propagation was estimated using a Range-dependent Acoustic Model (RAM) simulator (Širović et al. 2015b).

The propagation models were run for four different frequencies $(20,45,100$, and $350 \mathrm{~Hz})$, corresponding to the frequencies of dominant portions of different call types (Table S4). These models were run along 16 radials that were centered at each recording location and were $200-\mathrm{km}$ long for blue and fin whale frequencies and 100-km long for other species' models. Parameters needed for range estimation were specific to each call type (Table S4). Other assumptions used included the use of average noise values from August for each site and a 2-dB detectability level for each call type.

The resulting detection areas (Table S5) were used to normalize automatically detected blue whale B calls and the fin whale acoustic index (representative of $20-\mathrm{Hz}$ calls). All other call types were reported as hourly presence or total minutes of calling and it was not meaningful to normalize these metrics by detection area. However, detection areas were still reported for all low-frequency call types as a reference within this study and for comparisons to other acoustic studies where detection area is a relevant factor to interpreting results.

\section{Data analyses}

To compare across-site variation in species presence, the relative daily presence of detections was calculated for individual sites. Because we report detections using three different metrics, dependent on call type and detection methodology, for this analysis we used the total number of days with detections for a given call type as a unifying metric. To examine spatial patterns of odontocete occurrence, relative daily presence was calculated for each site as the percentage of days that each species was present out of the total number of days with acoustic presence for all species being compared. The total number of days with acoustic presence for each species are provided in Table S6 (variable DetDays). To examine seasonal patterns of the most commonly occurring cetaceans, relative seasonal presence was calculated for an individual species as the percent of days with acoustic presence during each season from one full year of data. To account for different recording periods and avoid periods when two different detections methods were used, data from the following time periods were used for each site: 7 September 2013-6 September 2014 at Kenai Shelf; 9 September 2013-8 September 2014 at Kodiak Shelf; 1 July 2013-30 June 2014 at Slope for Stejneger's beaked whales; 1 January 2014-31 December 2014 at Slope for blue whales; 1 July 2013-31 March 2014 and 1 April 2015-30 June 2015 at Quinn; 10 September 2012-31 July 2013 and 1 August 2014-9 September 2014 at Pratt. Seasons are defined as winter: December-February; spring: March-May; summer: June-August; fall: September-November. The spatial plots do not account for the effort variations at each site, and neither spatial nor seasonal plots account for the different detection ranges across sites and call types.

To examine spatial and temporal patterns within and between species in greater detail, call detection metrics were grouped into weekly bins to examine seasonal patterns, and into monthly bins to examine interannual changes for each site. For detections reported in hourly bins, acoustic presence was reported as average daily hours per week or per month, for seasonal and interannual plots, respectively. For detections reported as encounters, acoustic presence was reported as the average daily minutes of detections, again, per week or per month. For blue whale B call automatic detections, the total number of calls was normalized by the detection area for each site (Table S5), resulting in average daily detections per week (or per month) per $1000 \mathrm{~km}^{2}$ for seasonal (or interannual) plots. For fin whale $20-\mathrm{Hz}$ calls reported as average fin whale acoustic index, normalization accounted for transmission loss (TL) as well as the detection area (Table S5), as described by Širović et al. (2015b). Therefore, automatically detected $20-\mathrm{Hz}$ calls are reported as the average daily index per week (or month) per $1000 \mathrm{~km}^{2} /$ TL for seasonal (or interannual) plots. Diel plots (detections versus time of day) were also created to determine if there were any changes in calling between day and night for each call type, except for fin whale $20-\mathrm{Hz}$ calls.

Since recording effort varied across years and between sites, it was necessary to take these differences into account in our analysis. For seasonal plots, the number of weeks with effort was accounted for when averaging the weekly detection metric across years. Figure 2 allows for a comparison of the number of years with effort during each week at all five sites. For the interannual plots, effort is noted on the second y-axis to show the percent of effort for a given month. Additionally, generalized additive models (GAMs) were used to examine seasonal and interannual variation of daily detections for each species at each site. Models were created using a Tweedie distribution and a log link function using the $m g c v$ package (Wood 2011) in R Core Team (2020). The total number of calls, hours with call presence, or minutes of detections (dependent on species) each day were summed and used as the response variable. Predictor variables for the model were Julian day and year. Julian day was modeled with a smooth function that was estimated by a cyclic cubic regression spline with up to 4 degrees of freedom and year was modeled as a factor. Models were not developed for call types that were only detected on a few days (i.e., blue whale CenPac calls at Kenai Shelf, gray whale M3 calls at Slope and Quinn, North Pacific right whale upcalls, or killer whale 
HFM), or in instances where multiple detection methods were used and observations were only available during one year (i.e., blue whale B call manual detections at Quinn and fin whale $20 \mathrm{~Hz}$ manual detections at Kodiak Shelf).

\section{Results}

Mysticete species were more common on the continental shelf and slope, while odontocetes were generally more common farther offshore. However, the distribution of odontocetes showed spatial variation; killer whale whistles and pulsed calls were most common on the shelf, sperm whales and Stejneger's beaked whales were more common on the slope, and Baird's and Cuvier's beaked whales were more common at the seamounts (Fig. 3). In addition to these large spatial trends, there were also seasonal trends in detections. Blue whale CenPac and D calls, fin whale 40-Hz calls, and gray whale M3 calls were more prevalent in the spring and summer and blue whale B calls, fin whale $20-\mathrm{Hz}$ calls, and humpback whale calls were more prevalent during the fall and winter (Fig. 4). Beaked whale species also showed different seasonal distributions, with Stejneger's acoustic presence highest during fall, Cuvier's during winter, and Baird's during spring (Fig. 4). There were no detections of North Pacific right whales beyond those described by Širović et al. (2015a); therefore, results for this species will not be discussed further. We describe spatial, seasonal, diel, and interannual patterns in calling for all other species below in more detail. GAM results and interannual plots for all species and call types are provided as electronic supplementary material (see Table S6 and Figs. S2-S13).

\section{Blue whales}

The three blue whale call types examined were detected at all sites. B calls were the most prevalent blue whale call type in the GoA; they were detected in the highest numbers at Kodiak Shelf and Slope and were lowest at Kenai Shelf and Quinn. These calls occurred seasonally from May to February but peaked during the summer or fall at all sites (Fig. 5). CenPac calls were manually detected in the highest numbers at the two seamount sites, Quinn and Pratt, and in lowest numbers at the two continental shelf sites, Kenai and Kodiak Shelf. These calls occurred seasonally from May to October, peaking in July and August (Fig. 5; Kenai Shelf plot not shown due to low detections that occurred only on two days in July 2011 and one day in August 2014). Blue
Fig. 3 Relative daily presence of odontocete species at five sites in the Gulf of Alaska. Recording effort varied at each site (Fig. 2). Sperm whales are shown in dark blue, killer whale call types in shades of green, and the three beaked whale species in shades of red

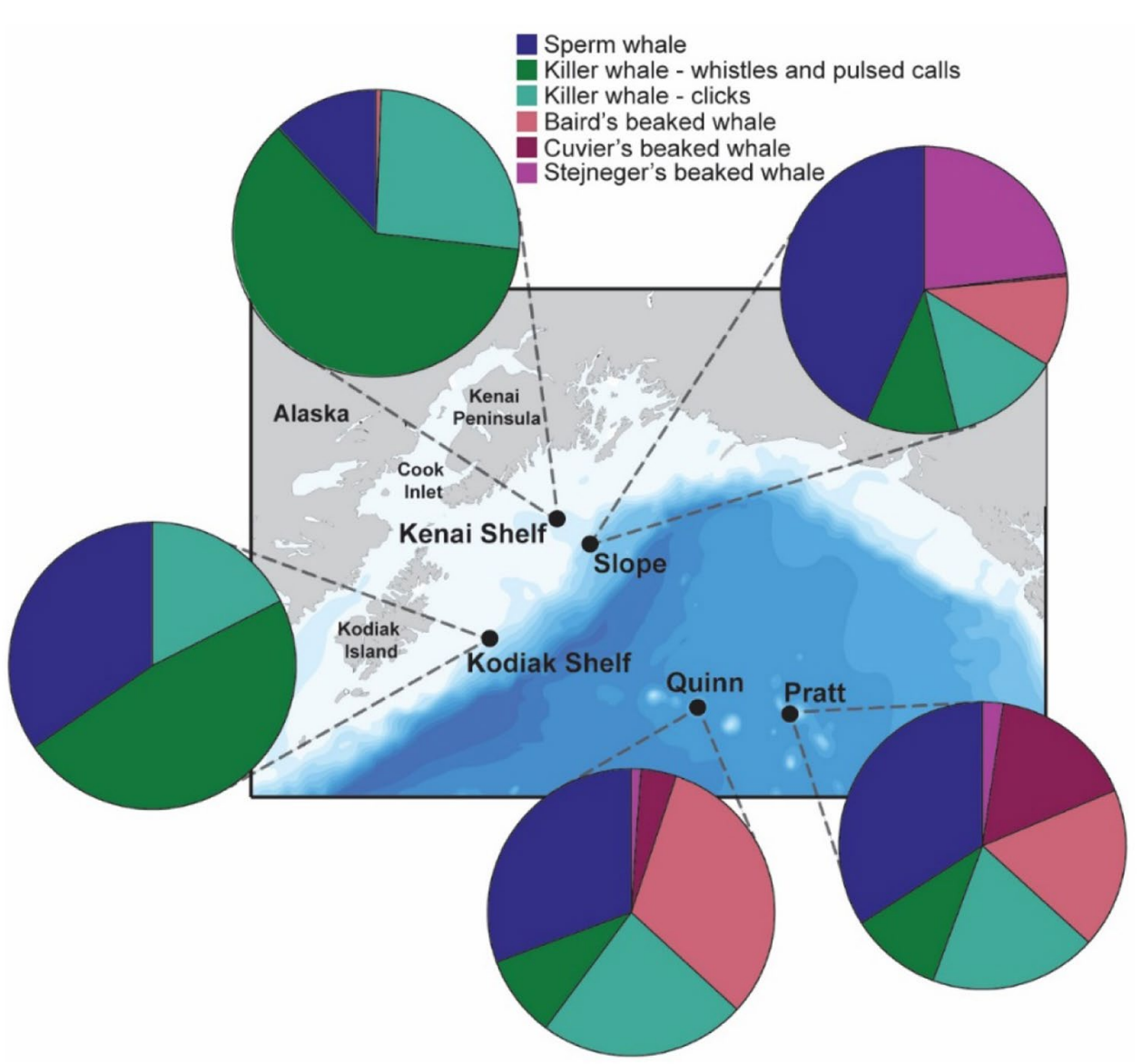




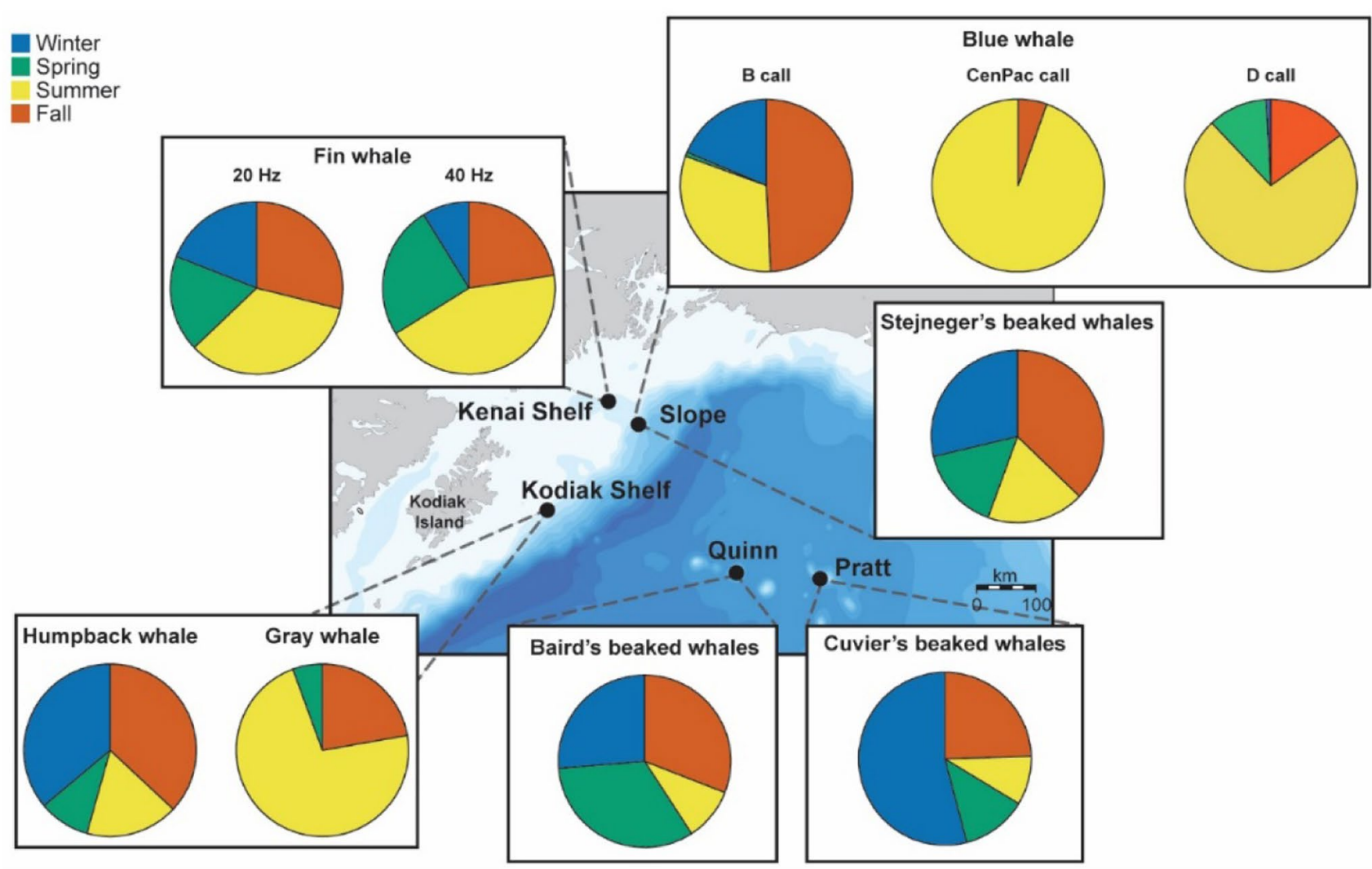

Fig. 4 Relative seasonal presence of select species during one year of data (see Data analyses in Methods for exact time periods used) at five sites in the Gulf of Alaska. Species are shown for the site at which the combined acoustic presence of all analyzed call types was generally highest. Fin whale call types are shown for Kenai Shelf,

whale D calls were manually detected in similar numbers across all sites except Kenai Shelf, where manual detections were the lowest. While low levels of D calls occurred during much of the year in the GoA, there was a peak during the spring and summer (Fig. 5). At Slope and both seamount sites, there was a bimodal peak in D calls; at Pratt, there was a peak during April and then again in July; while at Quinn and Slope, there was a peak in early June and again in July (Fig. 5). Although Kodiak Shelf also had peak calling in early June, calls persisted in June and July and again September through November (Fig. 5). D calls were the only blue whale call type with a potential diel pattern. At all sites except Kenai Shelf, D call presence was lower during the middle of the night during the spring and summer (Fig. 6a). Interannually, for all three blue whale call types at Slope (the only site with recording effort each year), there appeared to be a decrease in the number of calls detected during 2014 and 2015, compared to earlier years (Fig. 7). GAMs supported that generally fewer detections were recorded in 2014 and 2015; this was true across the board for D calls but humpback and gray whale calls are shown for Kodiak Shelf, blue whale call types and Stejneger's beaked whale clicks are shown for Slope, Baird's beaked whale clicks are shown for Quinn, and Cuvier's beaked whale clicks are shown for Pratt

was not significant at all sites for the other two call types (Table S6; Fig. S2).

\section{Fin whales}

Both fin whale $20-\mathrm{Hz}$ calls and $40-\mathrm{Hz}$ calls were detected at all sites. The fin whale $20-\mathrm{Hz}$ acoustic index was highest at Slope and lowest at the two seamount sites. These calls occurred year-round but there was a peak in the acoustic index during the fall and winter at all sites (Fig. 8). 40-Hz call manual detections were highest at the two continental shelf sites. At Slope, $40-\mathrm{Hz}$ calls had more hours of occurrence during the spring, summer, and early fall. At all other sites, these calls fluctuated throughout the year with no clear seasonal pattern (Fig. 8). There was no clear diel pattern for $40-\mathrm{Hz}$ calls, and we were unable to investigate whether there was a diel pattern for $20-\mathrm{Hz}$ calls because the energy detector used for most sites provides an average daily index. $20-\mathrm{Hz}$ calls were significantly higher during 2013 and 2014 at Slope and during 2014 at Kenai Shelf, but were lower 


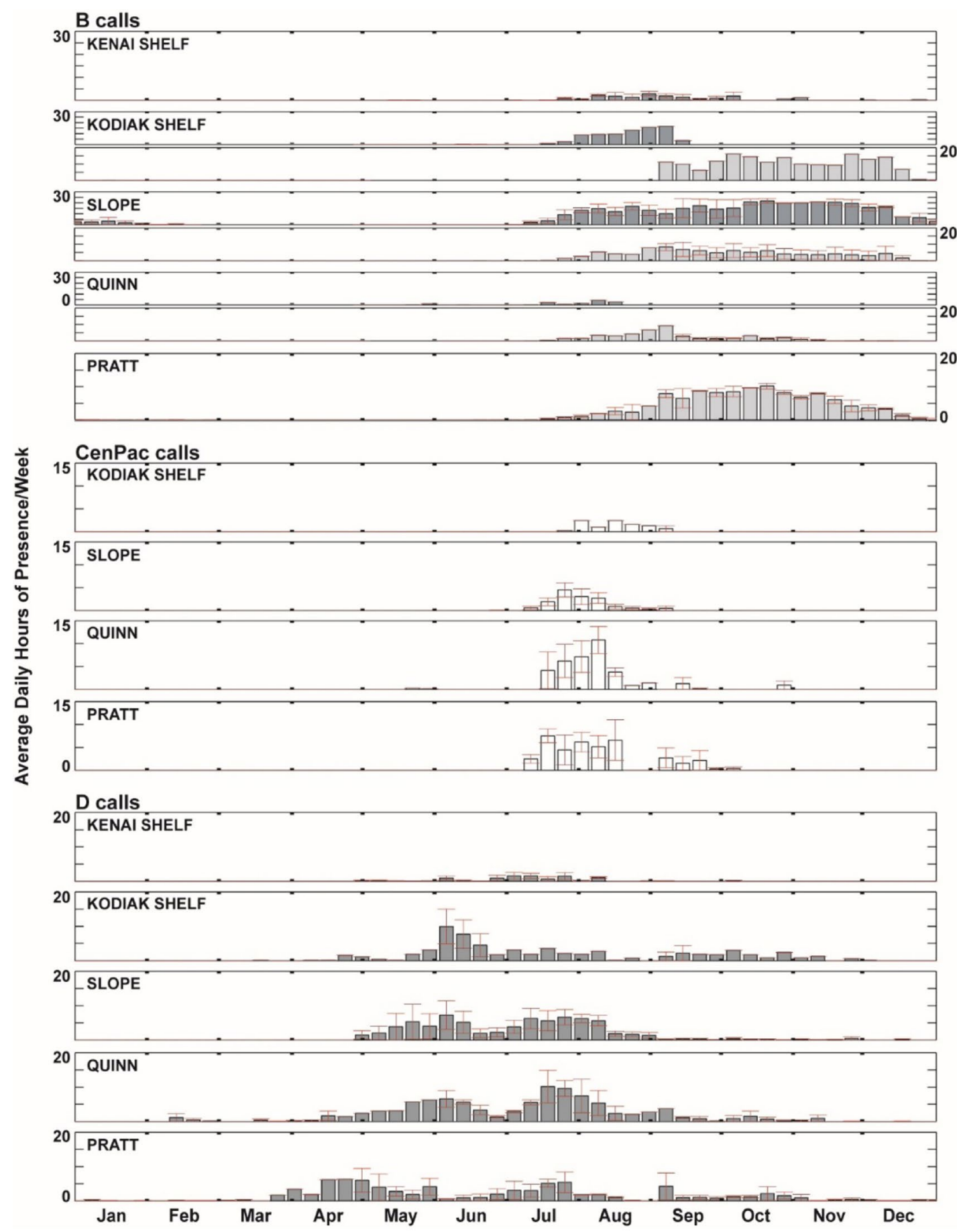

Fig. 5 Mean weekly presence of blue whale B calls (dark gray bars indicate manual detections; light gray bars indicate automatic detections), CenPac calls (white bars), and D calls (gray bars) at five locations in the Gulf of Alaska (only four sites are shown for CenPac

during 2015 at Quinn (Figs. 7 and S4; Table S6). Meanwhile, 40-Hz calls were high during 2013 at Pratt, but low during 2014 at Kodiak Shelf and Slope, and during 2015 at Slope (Figs. 7 and S4; Table S6). 

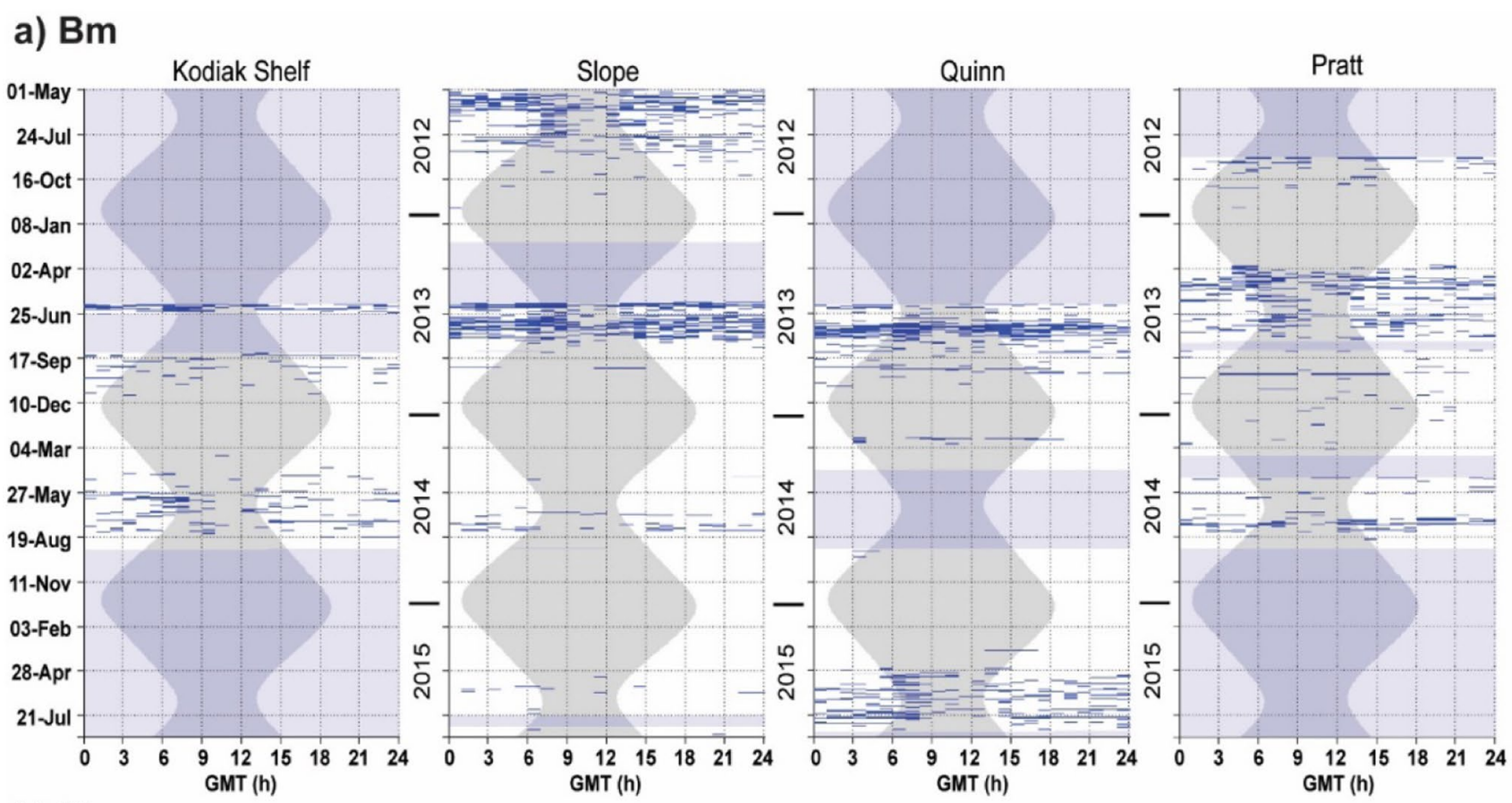

\section{b) $\mathrm{Mn}$}
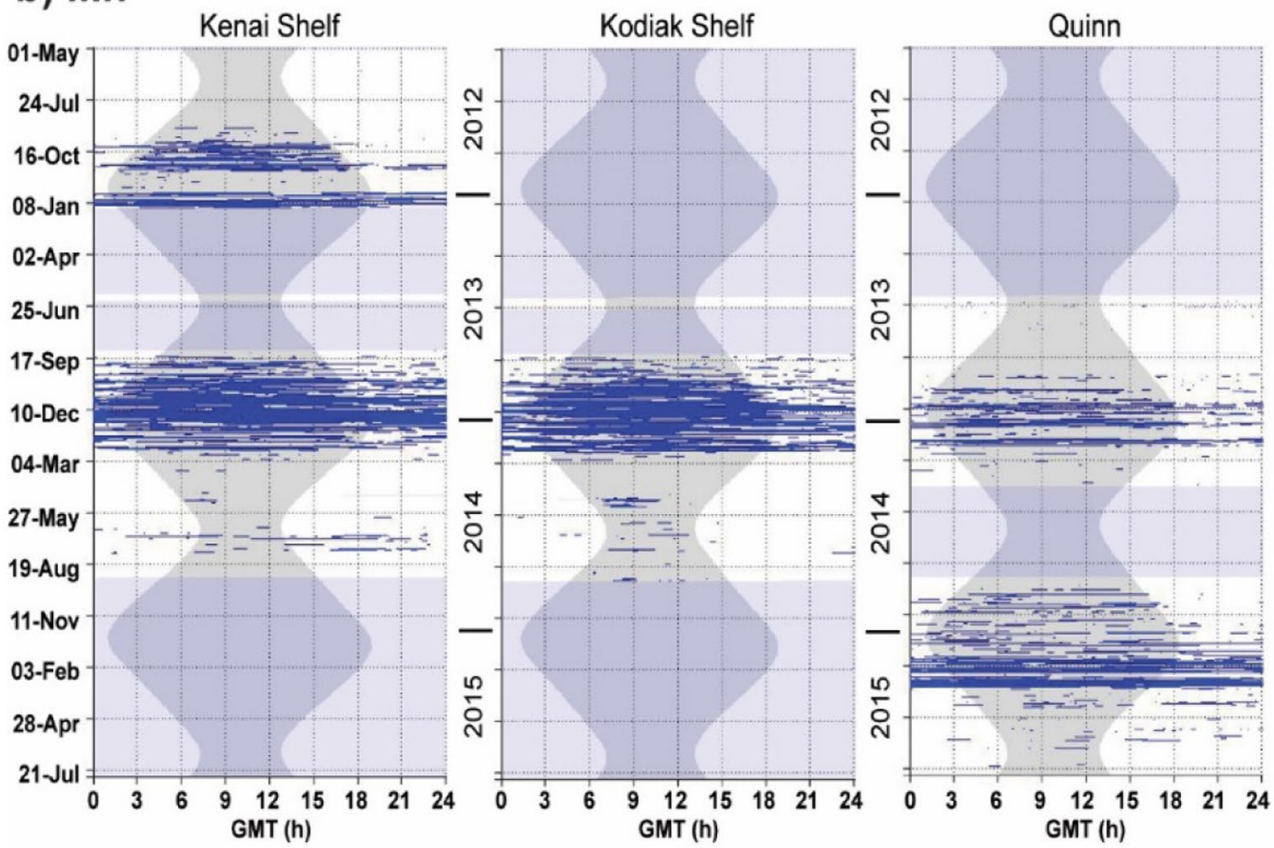

Fig. 6 Diel presence (blue lines) of (a) blue whale (Bm) D calls in one-hour bins at Kodiak Shelf, Slope, Quinn, and Pratt and (b) humpback whale $(\mathrm{Mn})$ calls in one-minute bins at Kenai Shelf, Kodiak

Shelf, and Quinn from 2012 to 2015. Gray vertical shading denotes nighttime and light blue shading denotes absence of recording effort

but there was a strong seasonal pattern with the majority of manually validated detections beginning in late fall and continuing through the winter (Fig. 9). The highest number of calls occurred at Kenai Shelf and Kodiak Shelf, while Slope showed the lowest (Fig. 9). When calling increased during the fall and winter, Quinn and Pratt had opposite peaks in calling; calls were higher at Pratt during the fall, while they

were higher at Quinn during the winter (Fig. 9). Although there was not a consistent diel pattern across seasons, there were periods during the fall when calls occurred less often after sunrise. This occurred at Kenai Shelf in 2012, Kodiak Shelf in 2013, and Quinn in 2014 (Fig. 6b). Overall, there was no clear interannual pattern across sites. 


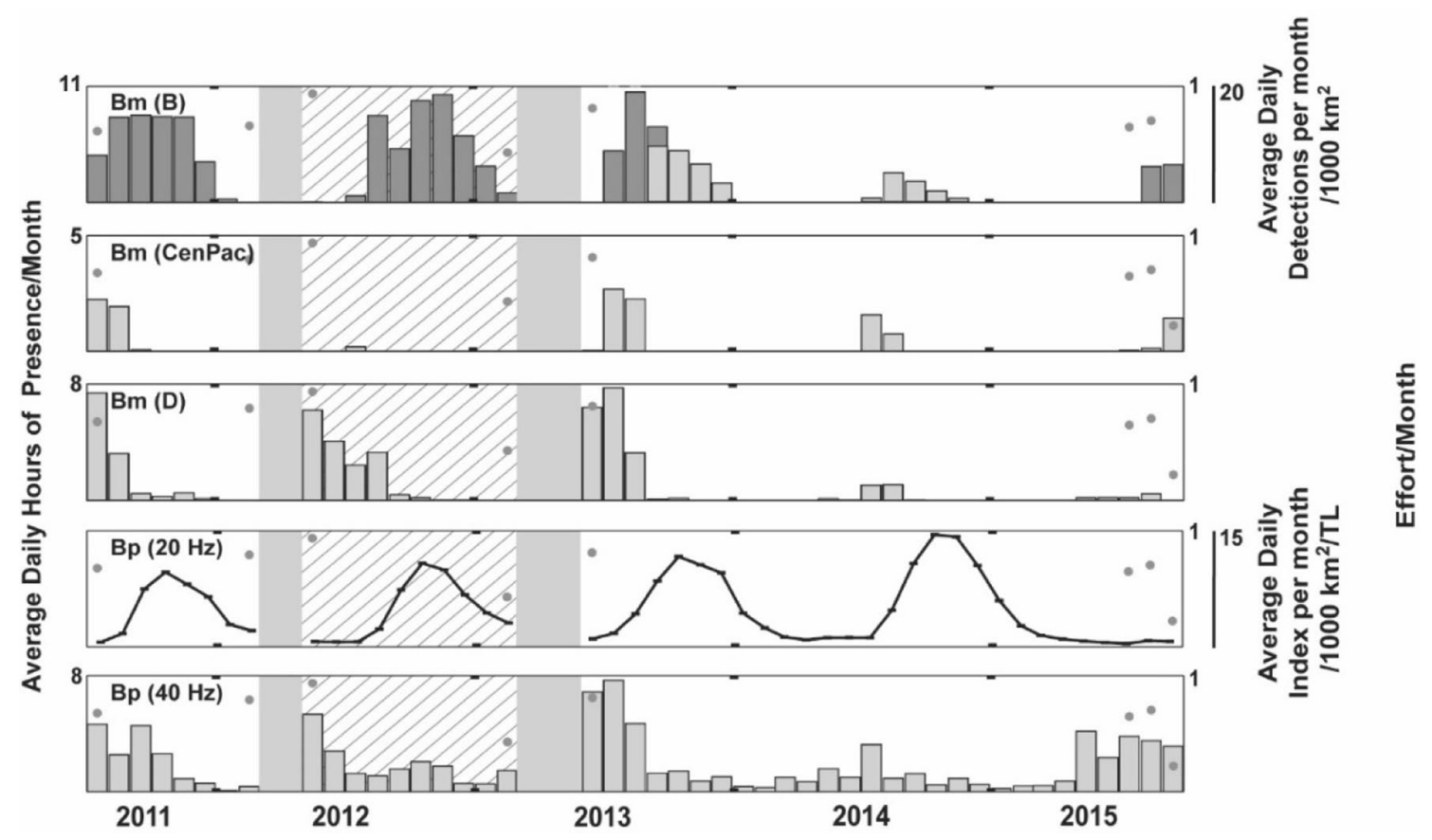

Fig. 7 Monthly presence (gray bars and black line) of blue whale (Bm) and fin whale (Bp), call types from 2011 to 2015 at the Slope site in the Gulf of Alaska. Note multiple y-axes for B calls due to use of multiple detection methods (dark gray bars for manual detec-

\section{Gray whales}

Gray whale M3 calls were manually detected in low numbers, intermittently from May to October at nearly all sites, with most calls occurring during the summer. Calls were highest at Kodiak Shelf and lowest at Quinn (Fig. 9; Slope and Quinn plots not shown). At Slope and Quinn, manual detections occurred only during 2015; there were 5 days in July and one day in August with acoustic presence at Slope, while at Quinn, there was one day in June and two days in July. No calls were manually detected at Pratt. There were no clear diel or interannual trends for M3 calls at any site, likely due to the low number of manual detections overall.

\section{Sperm whales}

Sperm whale clicks were manually detected at all five sites but were highest at Slope and very low at Kenai Shelf (Fig. 10; Kenai Shelf plot not shown due to low, sporadic clicks from January to August). The majority of clicks on the continental shelf occurred during the spring and summer, while those on the Slope and the two seamount sites occurred year-round (Fig. 10). Although there was a slight peak in manual detections at Slope in spring and a decline during the winter, there was no clear seasonal pattern at these offshore sites. There was no discernable diel or interannual pattern for sperm whale clicks at any site. tions and light gray for automatic detections are shown overlapping). Gray dots denote months with $<100 \%$ recording effort, gray shading denotes periods with no recording effort, and diagonal hatching denotes periods with duty cycled recordings

\section{Killer whales}

All three killer whale call types were manually detected at all sites, but whistles and pulsed calls were the most common at all five sites year-round, while HFM signals were very rare. Killer whale whistles and pulsed calls were highest at the two continental shelf sites and lowest at the two seamount sites (Fig. 11). Slope showed a clear seasonal pattern, with whistles and pulsed calls occurring primarily during the spring and early summer (Fig. 11). There was no diel or interannual pattern for killer whale whistles and pulsed calls at any site.

Killer whale clicks also occurred year-round at all sites but were highest at Quinn, where a seasonal peak occurred spring and summer (Fig. 11). There was no clear diel pattern for killer whale clicks and, while manual detections appear low at Slope in 2013, there was no clear interannual pattern (Fig. S11).

Although HFM signals were manually detected at every site, calls were sporadic and occurred in very low numbers. Pratt had six HFM signal encounters on separate days across all seasons (January 2013, June 2013, July 2013, October 2013 and two in November 2013). There was one encounter in June 2012 and 2014 at the Kenai Shelf and Slope, respectively. At Kodiak Shelf, there were four encounters on three separate days during fall and winter months (September 2013, two in October 2013, and January 2014). At 


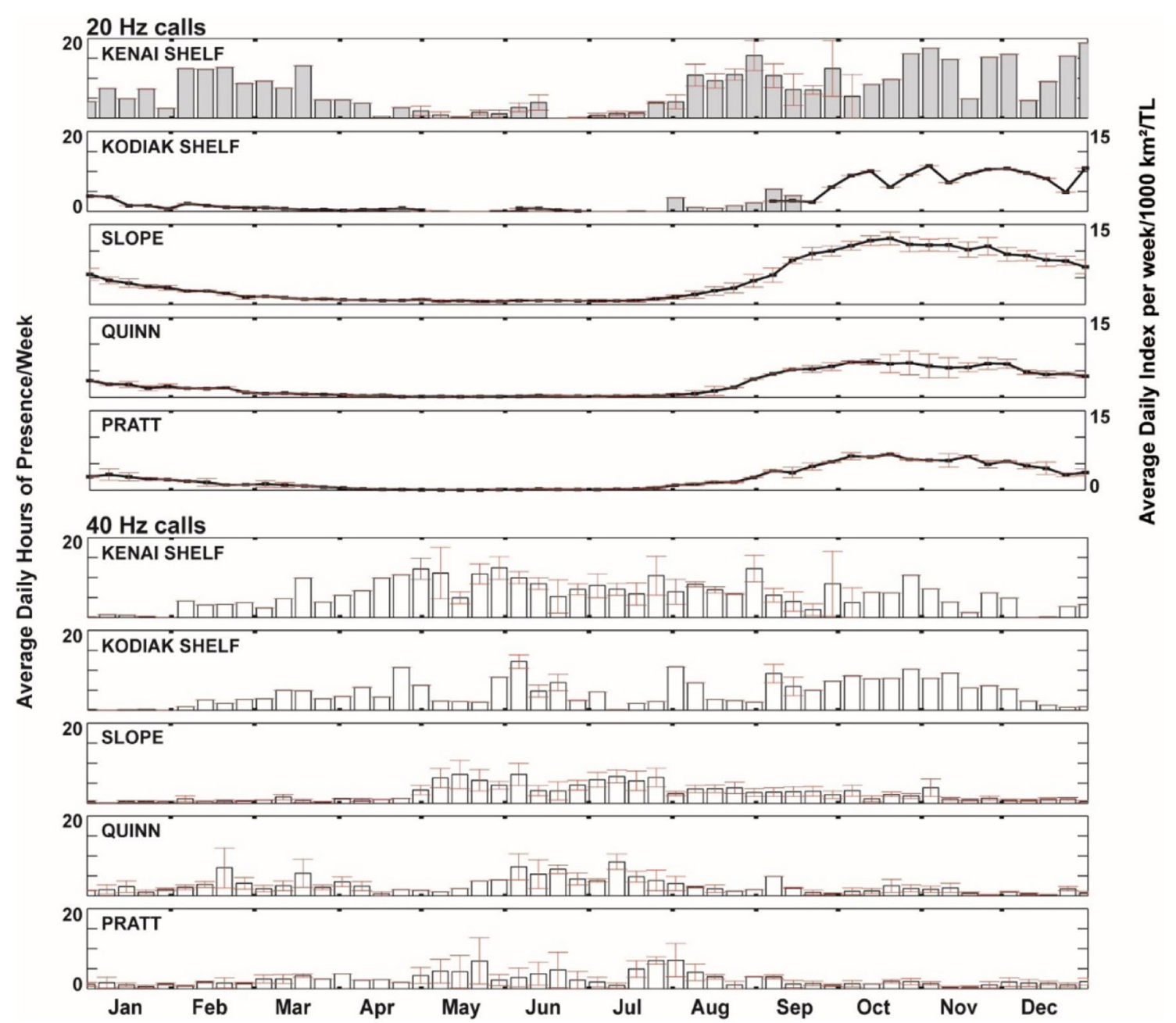

Fig. 8 Mean weekly presence of fin whale $20-\mathrm{Hz}$ (light gray bars and black line) and $40-\mathrm{Hz}$ (white bars) calls at five locations in the Gulf of Alaska. Data were averaged across years with recording effort from 2011 to 2015; red error bars represent standard error. The num-

Quinn, there were three encounters on the same day in September 2013 and one encounter in December 2014. While there were too few HFM signals to determine any seasonal, diel, or interannual patterns, or run GAMs, 12 out of the 16 encounters occurred in 2013 (Fig. S11).

\section{Beaked whales}

Baird's beaked whale clicks occurred almost entirely at Slope and the two seamount sites; there were only two days with one acoustic encounter each day at Kenai Shelf (one in June 2014 and the other in August 2014; Kenai Shelf plot not included in Fig. 12) and none at Kodiak Shelf (Fig. 12). Clicks were highest overall at Quinn and very low at Pratt. At Slope, manual detections mainly occurred from late fall through the winter, while at Quinn, they peaked in the late winter and early spring (Fig. 12). There was no clear diel or ber of years with recording effort for each week is shown in Fig. S1a. Note multiple y-axes for $20-\mathrm{Hz}$ calls due to use of both manual (light gray bars) and automatic detection (black line) methods at Kodiak Shelf site

interannual pattern for Baird's beaked whale clicks at any site, although the number of encounters did fluctuate over the years (Fig. S13).

The two other beaked whale species detected were Cuvier's and Stejneger's beaked whales. Clicks of both species were noted at Slope, Pratt, and Quinn (Fig. 12). For Cuvier's beaked whales, manually validated detections were most common at Pratt during winter (Fig. 12). Manually validated detections at Slope and Quinn also occurred mainly during the winter but were quite rare (Fig. 12). Stejneger's beaked whale echolocation clicks were most common at the Slope and occurred throughout the year with a peak in the early fall (Fig. 12). At Pratt and Quinn, Stejneger's beaked whale clicks were very sporadic throughout the year (Fig. 12). There was no clear diel pattern or interannual change for either Cuvier's or Stejneger's beaked whale clicks at any site. 

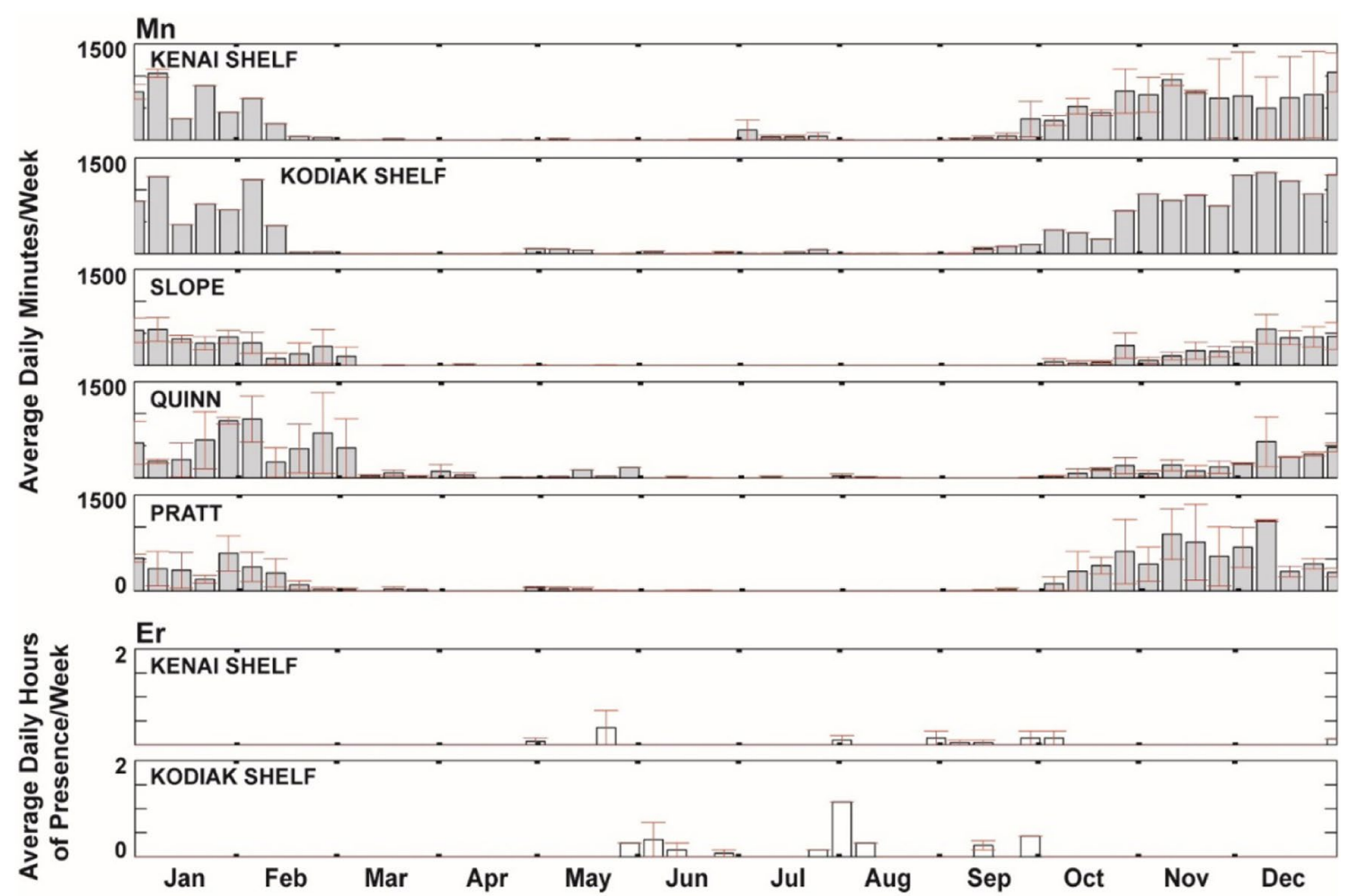

Fig. 9 Mean weekly presence of humpback whale (Mn; light gray bars) and gray whale calls (Er; white bars) at five locations in the Gulf of Alaska (only two sites are shown for gray whales). Data were averaged across years with recording effort from 2011 to 2015; red error bars represent standard error. The number of years with recording effort for each week is shown in Figs S1a and b for gray and humpback whales, respectively

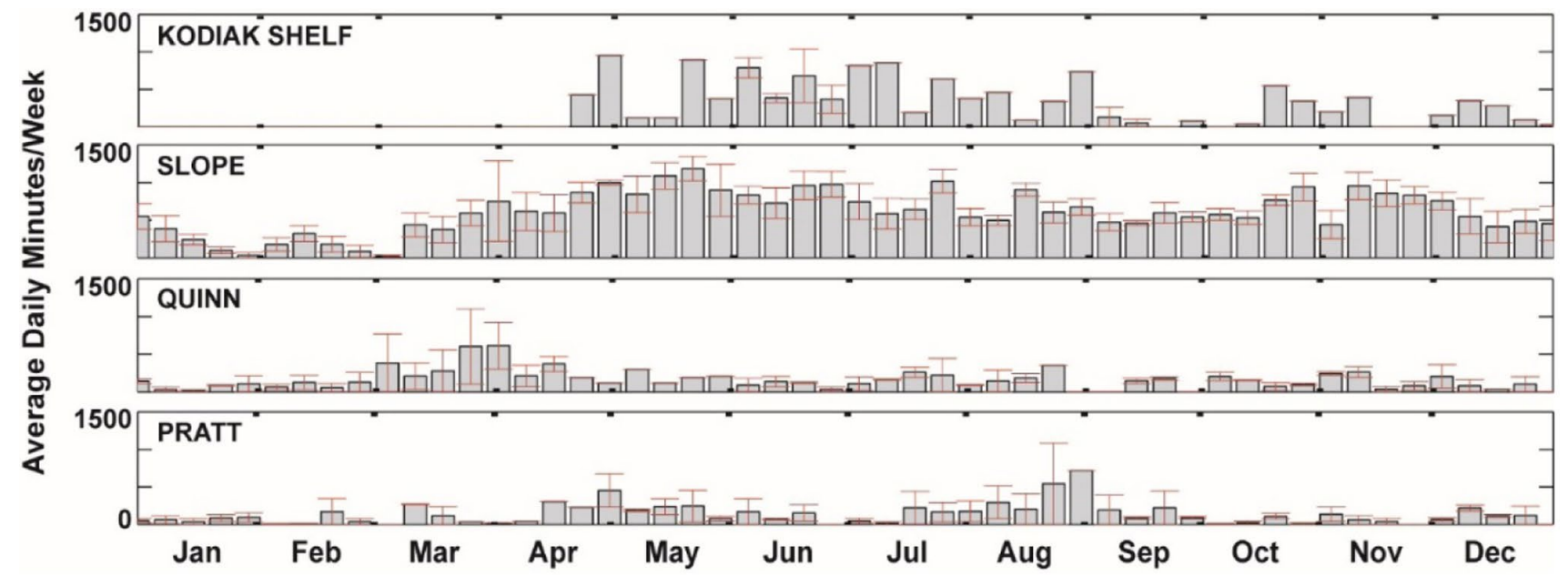

Fig. 10 Mean weekly presence of sperm whale clicks (light gray bars) at four locations in the Gulf of Alaska. Data were averaged across years with recording effort from 2011 to 2015; red error bars represent standard error. The number of years with recording effort for each week is shown in Fig. 2 


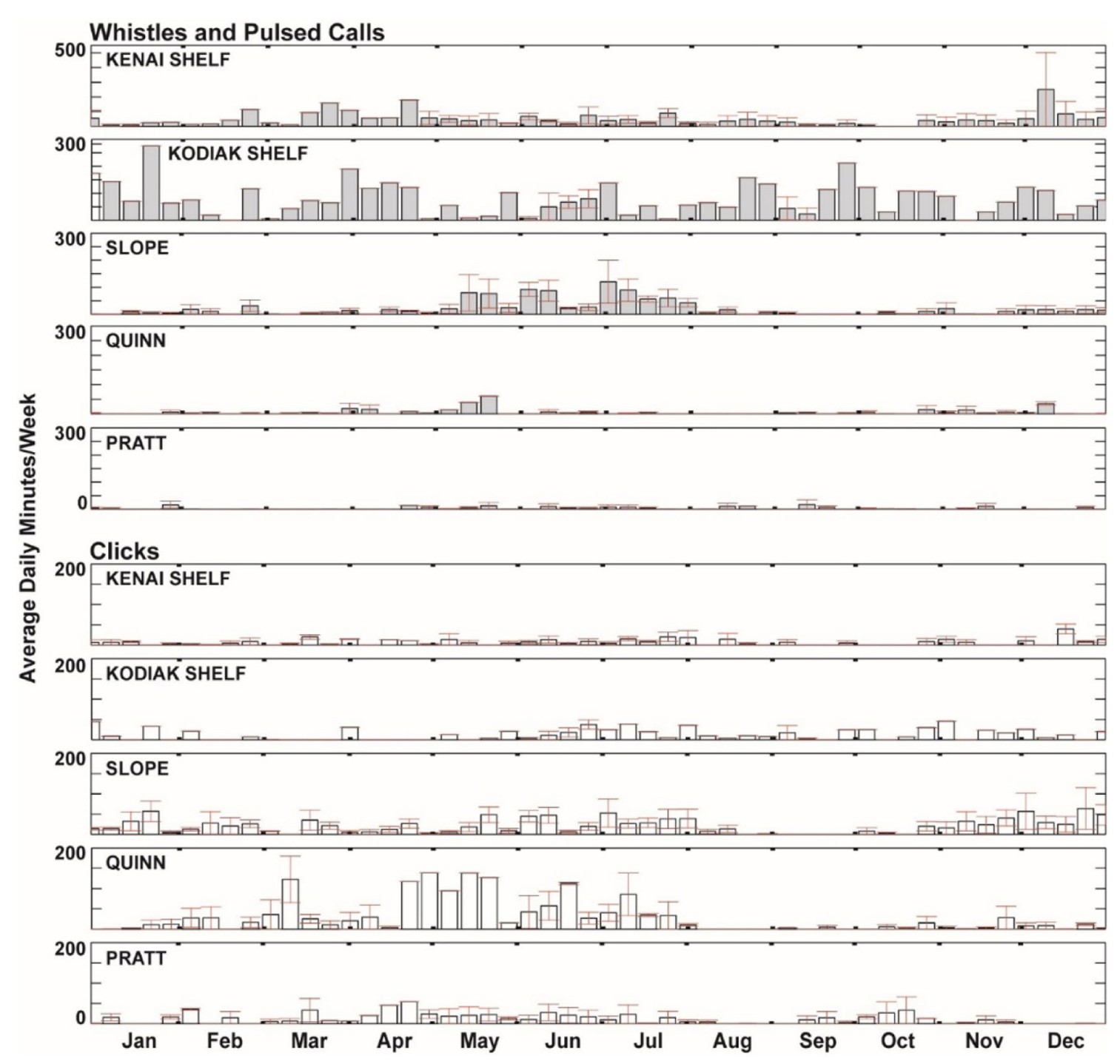

Fig. 11 Mean weekly presence of killer whale whistles and pulsed calls (light gray bars) and clicks (white bars) at five locations in the Gulf of Alaska. Data were averaged across years with recording effort

\section{Discussion}

In general, mysticetes were detected on or along the continental shelf while odontocetes were detected at sites farther offshore. Different spatial distributions were observed between blue whale call types that may relate to the presence of different populations. There were also spatial differences in the acoustic presence of killer whale call types, indicative of possible ecotype separation. Temporal separation was evident among blue whale call types, with foraging-related $\mathrm{D}$ calls detected before reproduction-related $\mathrm{B}$ and CenPac calls. Similar separation, but less pronounced, was also true for fin whale 20- and 40-Hz calls. Meanwhile, beaked whale species exhibited both potential spatial and temporal separation. Seasonal patterns were evident for most species, but from 2011 to 2015; red error bars represent standard error. The number of years with recording effort for each week is shown in Figs. S1b and 2 for whistles and pulsed calls and clicks, respectively

were more consistent across sites for baleen whales. Diel calling patterns were present only for blue whale $\mathrm{D}$ calls and humpback whale calls. Notable long-term changes were a decrease in detections of blue whales in later years at Slope, where detections of fin whale $20-\mathrm{Hz}$ calls increased.

Overall, blue, fin, and humpback whales were the most frequently detected mysticetes, while sperm whales were the most frequently detected odontocete. During three visual surveys that took place in our study area from 2009 to 2015, humpback whales and fin whales were sighted most frequently (Rone et al. 2017). As noted by Rone et al. (2017), conducting visual surveys for deep-diving species, such as sperm whales, can prove challenging, and utilizing acoustic methodologies often improves abundance estimates. The frequency of blue and sperm whale detections in our study 


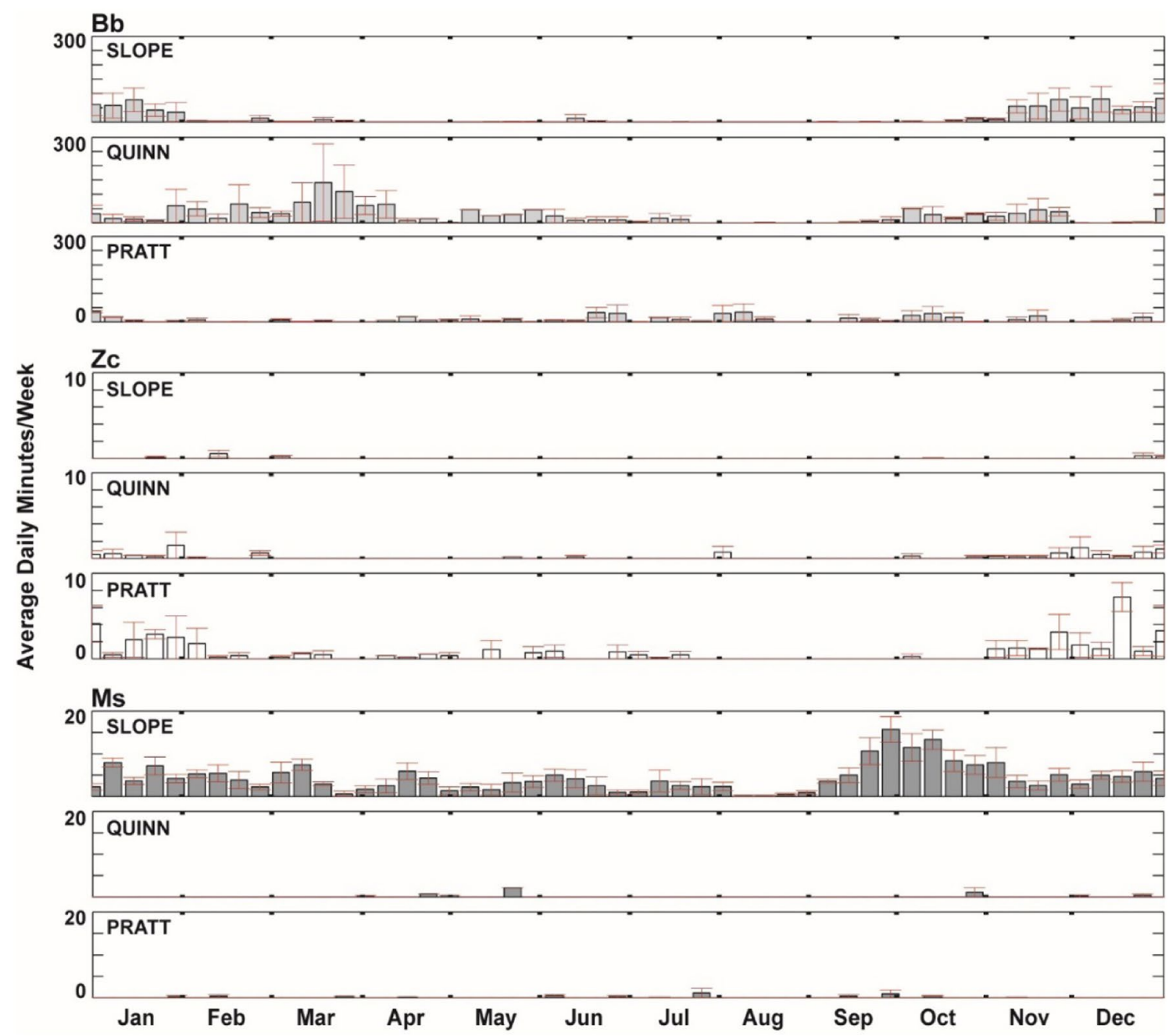

Fig. 12 Mean weekly presence of Baird's (Bb; light gray bars), Cuvier's (Zc; white bars), and Stejneger's (Ms; gray bars) beaked whale FM pulses at three locations in the Gulf of Alaska. Data were aver-

supports this assertion that it is necessary to combine visual and acoustic methods to gain a more complete picture of marine mammal distribution, especially across large and remote regions like the GoA.

\section{Mysticetes}

The spatiotemporal distribution of mysticete species was generally consistent with findings from previous surveys in the GoA (Brueggeman et al. 1987, 1988; Zerbini et al. 2006; Stafford et al. 2007; Rone et al. 2017), highlighting stable habitat use over decades. Even though these distributions were consistent on a large scale, by analyzing a variety of acoustic signals across a range of habitats, we can examine these spatiotemporal patterns in finer detail to both support and improve upon our ecological understanding of these species. aged across years with recording effort from 2011 to 2015; red error bars represent standard error. The number of years with recording effort for each week is shown in Fig. 2

Sightings of blue whales in the GoA have been extremely rare until recent years and have occurred almost entirely near seamounts and in pelagic waters (Calambokidis et al. 2009; Rone et al. 2017). However, we found that blue whales were also present on the continental shelf and slope, at least for a portion of the year (Fig. 5), indicating that the lack of blue whale sightings inshore during previous surveys (Brueggeman et al. 1987, 1988; Zerbini et al. 2006) may not relate to survey effort (Rone et al. 2017) and could instead indicate that blue whale distribution has shifted in recent years, possibly due to increased population levels as blue whales recovered from whaling (Calambokidis et al. 2009; Monnahan et al. 2015). Additionally, because we examined multiple call types for blue whales, we can gain further insights about their spatial distribution in the GoA. While B calls were detected at sites spanning from the continental shelf to offshore seamounts, CenPac calls were primarily detected at 
offshore sites (Fig. 5). These distinct distributions are likely a result of these call types being produced by different populations (Stafford et al. 2001, 2007; Stafford 2003; McDonald et al. 2006), indicating that the NEP population, producing B calls, is found throughout the GoA, while the CWP population, producing CenPac calls, does not range as close to shore in this region. Temporal differences in the peaks of B calls and CenPac calls are consistent with previously reported seasonal peaks for these call types (Stafford 2003). The third blue whale call type, the D call, is believed to be produced by blue whale populations worldwide (Thompson et al. 1996; McDonald et al. 2001; Mellinger and Clark 2003; Rankin et al. 2005). The spatial distribution of this call in the GoA seems to match the combined distribution of the B calls and CenPac calls (Fig. 5), supporting that hypothesis. The temporal shift from D calls in the spring to the reproductive calls (songs) in the summer and fall is likely related to a behavioral shift from foraging to mating. While this offset between D calls and reproductive calls has been documented before (Oleson et al. 2007b), we also found an unexpected bimodal peak in $\mathrm{D}$ call presence at Slope and the seamount sites (Fig. 5). This bimodality could be related to the presence of these two blue whale populations if one is present in the area earlier in the year. The early timing of the peak at Pratt could imply the arrival of the CWP population from the west, as suggested by Stafford et al. (2003). Concurrent secondary peaks, however, would imply the arrival of the NEP blue whales across the entire area. While the onset of the reproductive calls seems to be largely concurrent for both populations, CenPac call manual detections end much sooner than B call detections (Fig. 5), possibly indicating the earlier departure of the CWP population.

For fin whales, high levels of the $20-\mathrm{Hz}$ acoustic index at Slope and $40-\mathrm{Hz}$ manual detections at the two continental shelf sites (Fig. 8) are consistent with previous fin whale sighting records, which have typically occurred along the continental shelf and slope (Zerbini et al. 2006; Rone et al. 2017), although it is clear that fin whales can be found in pelagic waters as well (Stafford et al. 2007; Mizroch et al. 2009; Rone et al. 2017). Summer surveys along the continental shelf in the GoA reported the highest concentration of fin whales at an area southwest of Kodiak Island (Brueggeman et al. 1988; Zerbini et al. 2006), which is also considered a biologically important area for fin whale feeding (Ferguson et al. 2015). If fin whales are primarily feeding along the continental shelf then that could explain the higher number of $40-\mathrm{Hz}$ manual detections at the sites along the continental shelf, because $40-\mathrm{Hz}$ calls are believed to have some association with groups of whales, possibly engaged in foraging behavior (Watkins 1981). Because of this association with foraging, we expected a clearer transition from $40-\mathrm{Hz}$ calls earlier in the year to $20-\mathrm{Hz}$ calls later in the year, indicating a transition from feeding (Watkins
1981) to breeding (Watkins 1981; Watkins et al. 1987; Croll et al. 2002), as has been reported in other areas (Širović et al. 2013). Such a shift only occurred at Slope and the seamount sites (Fig. 8) and was not as apparent as the transition we observed between blue whale call types. While we did find a seasonal increase in $20-\mathrm{Hz}$ calls in the fall and winter, as has been reported previously in the GoA (Stafford et al. 2007) and in other areas (Širović et al. 2004, 2015b; Nieukirk et al. 2012), 40-Hz calls were produced year-round at both inshore and offshore sites, indicating year-round fin whale presence throughout the GoA (Figs. 4 and 8). Although the population structure of fin whales in the North Pacific is not well understood, and different fin whale populations may move in and out of the GoA throughout the year (Mizroch et al. 2009), year-round presence could indicate a resident population, as is speculated to exist in southern California and is known to occur in the Gulf of California (Forney and Barlow 1998; Berube et al. 2002; Širović et al. 2015b). A more detailed examination of patterns in $20-\mathrm{Hz}$ songs may offer insights into population structure and movements in this region (Oleson et al. 2014; Weirathmueller et al. 2017; Širović et al. 2017; Archer et al. 2020).

For humpback whales, we recorded higher calling at sites on the continental shelf, particularly at Kodiak Shelf, and seasonal peaks in calling during winter months at all sites (Fig. 9). Previous visual and acoustic surveys agree that humpback whales are most common on the continental shelf and that the area southeast of Kodiak Island supports a large aggregation of humpback whales (Consiglieri et al. 1982; Brueggeman et al. 1987, 1988; Waite et al. 1999; Zerbini et al. 2006; Stafford et al. 2007; Ferguson et al. 2015; Rone et al. 2017) and is considered a biologically important area for humpback whale feeding (Ferguson et al. 2015). However, humpback whale acoustic presence was also high at the seamount sites: at Pratt, calls were highest during early winter while at Quinn they were highest during late winter (Fig. 9). Rone et al. (2017) reported only a few humpback whale sightings around the seamounts and it is possible that the comparatively higher number of humpback whale calls at the seamounts than at Slope may be a result of the larger detection areas at the two seamount sites (Table S5). However, in New Caledonia, migrating humpback whales changed behavior around seamounts and often congregated near them, suggesting seamounts may represent an important habitat for humpback whales (Garrigue et al. 2015). Geographically, seamounts present a potential foraging location, but the persistence and increase of calls into winter may suggest that these detections were from humpback whales that were singing at the start or end of their annual migration to lower latitudes (Clapham and Mattila 1990; Norris et al. 1999; Warren et al. 2020).

The seasonal pattern we observed for humpback whale calling matches what is known about their acoustic behavior 
in the GoA; the primary call types produced are social and feeding calls which are often short and faint (Thompson et al. 1986; Wild and Gabriele 2014; Fournet et al. 2015, 2018b), and song, which typically consists of long sequences of relatively louder calls (Payne and McVay 1971), is produced mainly during fall and winter (Gabriele and Frankel 2002; Stafford et al. 2007). Therefore, even though we did not discriminate between song and non-song in this study, the seasonal pattern we report is most likely a result of winter song production. This is reinforced by the fact that our detections may be biased towards song if the short, quiet, social calls that have very low fundamental frequencies (Stimpert et al. 2011; Wild and Gabriele 2014; Fournet et al. 2015) were more likely to be missed by our detection algorithm. Additionally, the detection area for non-song calls was smaller than for song (Table S5) and the metric we used to describe humpback whale calling (daily minutes of calling) inevitably highlighted this seasonal difference in acoustic behavior more than a simple metric such as presence/absence would have. Humpback whale song production on feeding grounds is now a well-documented occurrence, which has led to hypotheses about some whales forgoing their annual migration in order to continue feeding throughout the winter (McSweeney et al. 1989; Gabriele and Frankel 2002; Clark and Clapham 2004; Stafford et al. 2007; Stimpert et al. 2012; Vu et al. 2012; Garland et al. 2013; Kowarski et al. 2018). In Alaska, there is evidence of humpback whales feeding on herring during winter months and of a small number of overwintering whales (Straley et al. 2018). However, the majority of the population does migrate each year and year-round sightings at high latitudes can likely be attributed to a staggered migration (Straley 1990; Straley et al. 2018), which could explain the winter calling we report here. Humpback whale abundance has been increasing in the North Pacific since the end of commercial whaling (Barlow et al. 2011; Teerlink et al. 2015; Gabriele et al. 2017) and so their presence at higher latitudes into the winter may be indicative of distributional shifts associated with increased competition for resources (Straley et al. 2018).

The spatiotemporal distribution of gray whale M3 call manual detections in the GoA is likely related to annual migration patterns. The majority of M3 calls occurred at the two sites on the continental shelf (Fig. 9), which is consistent with visual sightings of gray whales in the GoA (Moore et al. 2007; Rone et al. 2017). Gray whales have a known preference for traveling along the continental shelf when making their migration (Swartz et al. 2006), which likely explains the higher number of M3 calls at sites on the continental shelf. However, there were a few manual detections of M3 calls at Slope as well as offshore at Quinn (Fig. S7). These calls may have been produced by males or females traveling without calves that do not require the protection of the shallower water along the continental shelf (Burnham and Duffus 2020). It is also possible that gray whales travel beyond the shelf edge in the GoA more frequently than indicated by our sparse detections, but that they tend not to vocalize when traveling in deeper waters, potentially to avoid detection by killer whales (Crane and Lashkari 1996). Another possible explanation is that these manual detections were from western North Pacific gray whales traveling into the GoA and taking a different route than that taken by the eastern Pacific population. Tag and photo-identification data have shown that there is some overlap between these two gray whale populations in the GoA (Weller et al. 2012; Mate et al. 2015).

The bimodal timing of gray whale M3 call manual detections matched time periods when eastern Pacific gray whales would be expected to be passing through the GoA on their migration from breeding grounds off Baja, Mexico to feeding grounds in the Bering and Chukchi Seas (Rice and Wolman 1971; Consiglieri et al. 1982). These seasonal peaks in acoustic presence match visual survey observations (Brueggeman et al. 1987). The occasional presence of M3 calls throughout the summer could be explained by an overlap between individuals arriving on the feeding grounds and those departing for the breeding grounds, because factors such as sex, age, and whether or not a calf is present are related to migration timing (Rice and Wolman 1971). Alternatively, these calls may be from whales that are a part of the Pacific Coast Feeding Group, a subset of eastern North Pacific gray whales that are known to feed along the West Coast of the U.S. and Canada during the summer, instead of migrating further north (Calambokidis et al. 2002). It is also possible that these calls are from a resident population that feeds off Kodiak Island, where sightings have been reported year-round near Ugak Bay (Moore et al. 2007). Our lack of M3 manual detections in winter may be due to gray whales remaining near Ugak Bay, which is outside of the detection area for our Kodiak Island site (Table S5), or it may be that it is necessary to utilize additional gray whale signal types (Dahlheim 1987; Crane and Lashkari 1996; Burnham and Duffus 2020) to fully capture their temporal distribution in the GoA.

\section{Timing of baleen whale calls}

There was a temporal offset between when blue, fin, and humpback whale call detections increased during the year. Blue whale B calls started increasing in the summer, fin whale $20-\mathrm{Hz}$ calls in the late summer, and humpback whale calls in the early fall (Figs. 5, 8, and 9). The reason for this offset is currently unknown. Since these calls overlap throughout the fall and into the winter, it seems unlikely that this offset is a result of acoustic niche partitioning. Additionally, since at least blue and fin whales have relatively high acoustic presence in the GoA earlier in the year (based on 
the presence of other call types), it also seems unlikely that this offset is due to a staggered arrival in the GoA.

It is possible that this offset is related to prey, as calling increased first in blue whales, which feed only at one trophic level, followed by fin and humpback whales, which feed at higher trophic levels (Nemoto and Kawamura 1977; Witteveen 2008). Therefore, there may be a connection between the type of prey being consumed and the timing or duration of feeding. It is possible that feeding at higher trophic levels requires an increased number of attempts to consume enough food for the season, as studies have shown that feeding on less dense prey, such as schooling fish, can increase time between feeding attempts (Simon et al. 2012; Goldbogen et al. 2013). Further research into prey distribution in the GoA and the foraging ecology of these species would be required to determine if this phenomenon is related to prey.

A more probable hypothesis is that this temporal offset in calling may be related to seasonal fluctuations in hormones, as has been suggested previously (Clark and Clapham 2004; $\mathrm{Vu}$ et al. 2012). In many baleen whale species, males exhibit seasonal increases in testosterone (Kjeld et al. 2006; Vu et al. 2015; Hunt et al. 2018); the onset of calling might be linked to this increase in reproductive hormones. In particular, testosterone begins to increase in some fin whale populations in mid to late summer (Kjeld et al. 2006; Carone et al. 2019), while in humpbacks the increase starts in the fall ( Vu et al. 2015; Cates et al. 2019), matching the temporal offset in calling described here. If there is a link between increases in testosterone and acoustic behavior, this should be apparent in the timing of reproductive-related calling and testosterone increases in other baleen whale species and in other regions.

\section{Diel patterns}

Diel patterns were only discernable in blue whale D call and humpback whale call detections. For blue whale D calls, we found higher manual detections at dusk and, to a lesser extent, at dawn during seasonal peaks in call production (Fig. 6a). Increased presence of D calls at dusk has been reported previously in southern California (Lewis et al. 2018), where D calls are typically produced at shallow depths between bouts of foraging dives (Oleson et al. 2007a; Lewis et al. 2018). This diel variation in blue whale calling is believed to be related to the diel vertical migration of krill; when krill are closer to the surface at night, feeding is less efficient and blue whales engage in non-foraging behavior (Stafford et al. 2005; Wiggins et al. 2005; Lewis et al. 2018). Evidence of the increased production of blue whale B calls at night in southern California (Wiggins et al. 2005; Lewis et al. 2018) and in the eastern tropical Pacific (Stafford et al. 2005) originally gave rise to this theory and it is therefore interesting that we did not observe this same diel pattern in B calls. Leroy et al. (2016) reported an increase of Antarctic blue whale Z-calls during the day, likely related to the different prey types and behaviors in the region, and so the lack of B call diel variation in our data may relate to the different light regimes at our high-latitude study sites.

For humpback whales, we found an occasional diel pattern during the fall, which was most obvious at Kenai Shelf in 2012 and at Quinn in 2014 (Fig. 6b). During these periods, humpback whale acoustic presence was higher at night, with a noticeable decrease in encounters for a few hours after sunrise (Fig. 6b). This pattern was replaced by near-constant acoustic presence throughout the winter, most likely because this is when humpback whales engage in song production (Gabriele and Frankel 2002; Stafford et al. 2007). If we proceed with the assumption that the increase in acoustic presence during winter is due to song production, then this pattern in the fall could represent a transition period; non-song vocalizations are produced while engaged in other behaviors, such as foraging, until song starts being produced regularly throughout the winter. In other regions, song production is highest at night (Au et al. 2000; Huang et al. 2016; EspanolJimenez and van der Schaar 2018; Kowarski et al. 2018; Ryan et al. 2019). While this diel pattern is hypothesized to relate to foraging or mating behaviors that are most efficient during daylight hours (Helweg and Herman 1994; Au et al. 2000; Ryan et al. 2019), humpback whales show a high degree of behavioral plasticity (Stimpert et al. 2012) and so a closer examination of the call types recorded during these periods would be required to better understand how this changing diel pattern in the GoA may relate to the patterns observed in other regions. It is also important to note that the presence and strength of diel patterns in humpback whale calling can be impacted by variations in ocean noise (Helble et al. 2013; Fournet et al. 2018a) and the use of call metrics that account for detection probability (Helble 2013). Since the call metric we used for humpback whale call analysis did not account for noise conditions or call density, it is possible that the diel patterns we report are similarly impacted.

\section{Interannual differences in blue and fin whales}

During 2014, there was a decline in detections of blue whale $\mathrm{B}$ and D calls (Figs. 7 and S2; Table S6), as well as fin whale $40-\mathrm{Hz}$ calls, but an increase in fin whale $20-\mathrm{Hz}$ calls (Figs. 7 and S4; Table S6). In 2015, our recordings did not cover the full calling season for blue whale B calls and fin whale $20-\mathrm{Hz}$ calls, but blue whale D calls were still low, while fin whale $40-\mathrm{Hz}$ calls had increased. These interannual changes could be related to the marine heat wave that began affecting the GoA in 2013 and continued into 2015 (Bond et al. 2015). This event resulted in a decrease in phytoplankton production, ultimately impacting the entire ecosystem of the region (Whitney 2015; Cavole et al. 2016; Pena et al. 2019). 
Since blue whales feed primarily on krill, which feed on phytoplankton, the increase in sea surface temperature resulted in a decrease of blue whale prey (Peterson et al. 2017; Brodeur et al. 2019), which could explain the decrease in calls during this time period. Since fin whales also feed on krill in the North Pacific, the decrease in $40-\mathrm{Hz}$ calls may also be explained by this decrease in phytoplankton. However, the increase in $40-\mathrm{Hz}$ calls in 2015 , when blue whale D calls were still low, as well as the increase in fin whale $20-\mathrm{Hz}$ calls throughout this period, may indicate that these species were impacted in different ways. Because fin whales also feed at higher trophic levels (Nemoto and Kawamura 1977), their prey may not have been as immediately impacted by the increased water temperatures (von Biela et al. 2019), delaying the impacts of the marine heat wave a year or two. While our recordings did not capture the full $20 \mathrm{~Hz}$ calling period in 2015, there was a significant increase in fin whale strandings in the GoA during this year (Savage 2017). Although the causes of these strandings are unknown, they are believed to be linked to the ecological changes that were occurring in the region (Savage 2017). Analysis of more recent acoustic data would help with understanding how this event impacted blue and fin whales over the long term, but the interannual changes that we observed in their call detections could relate to the anomalous environmental conditions that occurred in the GoA during this time period.

\section{Odontocetes}

In general, killer whale acoustic presence was highest along the continental shelf (Fig. 11), sperm whale acoustic presence was highest at the continental slope (Fig. 10), and beaked whale acoustic presence was highest at the continental slope and offshore seamounts (Fig. 12). These distributional differences (Fig. 3), which support the findings of previous surveys in the region (Consiglieri et al. 1982; Brueggeman et al. 1987; Zerbini et al. 2007; Klinck et al. 2016; Rone et al. 2017) may relate to the different prey preferences of these species.

The ecological differences between the three killer whale ecotypes may relate to the unique distributions we observed for the three signal types we examined. The resident ecotype is most commonly sighted along the continental shelf, particularly around Kodiak Island (Consiglieri et al. 1982; Brueggeman et al. 1987; Zerbini et al. 2007; Rone et al. 2017). This is also the region where their main prey source, salmon (Ford et al. 1998; Saulitis et al. 2000; Ford and Ellis 2006), is typically distributed (Fisher et al. 2007; Trudel et al. 2009; Larson et al. 2013). The fact that whistles and pulsed calls were highest along the continental shelf may indicate that these calls were primarily from resident killer whales. Although the transient ecotype has also been sighted commonly around the continental shelf, though to a lesser extent than residents (Zerbini et al. 2007), this ecotype is known to vocalize at much lower rates than the other ecotypes, likely to avoid detection by their marine mammal prey (Barrett-Lennard et al. 1996; Deecke et al. 2005). Meanwhile, the offshore ecotype is more common in pelagic waters (Zerbini et al. 2007; Ford et al. 2014). The offshore ecotype is the only ecotype in the North Pacific to which HFM signals have been attributed (Samarra et al. 2010; Filatova et al. 2012; Simonis et al. 2012; Gassmann et al. 2013), although these signals have only once been linked to offshores in the GoA (Filatova et al. 2012). Discriminating between the pulsed calls of different ecotypes was beyond the scope of the current study, but that sort of fine-scale analysis has the potential to reveal whether the different distributions of the three killer whale call types we describe here are in fact related to the unique distributions of the different ecotypes that inhabit this region.

For sperm whales, the majority of sightings and acoustic detections in the GoA have been documented along the continental slope (Consiglieri et al. 1982; Brueggeman et al. 1987; Mathias et al. 2012; Straley et al. 2014; Klinck et al. 2016; Rone et al. 2017), as in this study, or in regions much farther offshore (Mellinger et al. 2004a; Diogou et al. 2019). In the GoA, sperm whales extensively use the continental slope for foraging (Mathias et al. 2012) and have increasingly been associated with vessels engaged in longline fishing for sablefish (Anoplopoma fimbrica) along the slope (Straley et al. 2014, 2015). While this preference for foraging along the continental slope explains the high acoustic presence we found at the Slope site, we also found relatively high acoustic presence at the Kodiak Island site (Fig. 10), which is located closer to the shelf break than the other continental shelf site (Kenai shelf). At Kodiak Shelf, a seasonal pattern in sperm whale clicks was evident, with very few clicks from January to March and the majority of clicks from April to September (Fig. 10). The longline fishery for sablefish runs from March to November and sperm whale associations with these fishery vessels peaked from April to August (Straley et al. 2015), presenting a possible explanation for the sudden onset of sperm whale clicks at Kodiak Shelf in April (Fig. 10). Although sperm whale clicks were recorded year-round at Slope, this site showed a similar seasonal pattern, with low acoustic presence in January and February and a peak in the spring.

While these patterns correspond with the longline fishery season for sablefish, movements of sperm whales may also be responsible for some of the patterns reported here, as sperm whale detections were also lowest during winter farther offshore in the GoA (Mellinger et al. 2004a; Diogou et al. 2019). This seasonal pattern may be due to sperm whales migrating out of the GoA during winter after spending the summer foraging in the region (Whitehead 2003). However, the presence of sperm whales in the GoA 
year-round has been reported previously and has resulted in a lack of consensus on sperm whale migration patterns (Whitehead 2003; Mellinger et al. 2004a; Diogou et al. 2019). Mellinger et al. (2004a) suggested that year-round presence at higher latitudes is due to mature males foregoing mating for the chance to continue feeding throughout the winter, or perhaps a result of immature whales foregoing mating to increase their fitness and maturity before engaging in the breeding season (Mellinger et al. 2004a). For sperm whales that transit to low latitudes, recent data from individuals tagged offshore of Sitka, Alaska revealed that they do not appear to synchronize their departure from the GoA, nor do they travel to the same locations (Straley et al. 2014). The seasonal peaks in acoustic presence we found at our seamount sites could be a result of such movements; sperm whales could be passing by the seamounts as they enter or leave the GoA, or they may aggregate around these features as has been reported in other areas (Hann et al. 2016). However, females have been sighted during winter near the Aleutian Islands (Fearnbach et al. 2012) and calving may occur offshore at high latitudes (Gregr et al. 2000), and so a better understanding of sperm whale demographics in the GoA would likely improve our understanding of habitat use in this region. Additionally, passive acoustics continue to be a valuable tool for gaining insights about pelagic species and it is important that we continue to gather information about sperm whale regional habitat use as, currently, there are no reliable abundance estimates for this endangered species in the North Pacific.

For beaked whales, the few documented sightings and acoustic detections that have previously been reported in the GoA have occurred in pelagic waters, near seamounts and on the continental slope (Brueggeman et al. 1987; Klinck et al. 2016; Rone et al. 2017), as we also found here (Fig. 12). Since we detected echolocation clicks, we presume that we detected beaked whales while they were foraging in the GoA (Johnson et al. 2004). Based on studies in Japan, Baird's beaked whales prey upon deep sea fish and squid, with the ratio of prey type varying in different locations (Nishiwaki and Oguro 1971; Walker et al. 2002; MacLeod et al. 2003). Cuvier's and Stejneger's beaked whales have both been reported mainly to prey upon squid, with Stejneger's consuming smaller individuals when in competition with Cuvier's beaked whales (MacLeod et al. 2003). We did not see a diel pattern in click detections for any beaked whale species. This likely means that beaked whales in the GoA are foraging both day and night, as has been documented before (Baird et al. 2008; Schorr et al. 2014; Shearer et al. 2019).

\section{Beaked whale habitat partitioning}

A closer examination of beaked whale distribution at the three offshore sites reveals the unique distributions of each species. Baird's beaked whale clicks were highest at Quinn Seamount, Cuvier's beaked whale clicks were most common at Pratt Seamount, and Stejneger's beaked whale clicks were most common at Slope (Fig. 12). In addition, when detected at the same locations, detection peaks were all temporally offset. At Slope, Stejneger's beaked whale clicks peaked in the fall, while Baird's beaked whale clicks peaked in the winter. At the seamounts, Baird's beaked whale clicks peaked in the spring, while Cuvier's beaked whale clicks peaked in the winter (Fig. 12). The spatial and temporal separation of these three species suggests some level of habitat partitioning in the GoA, whether to reduce competition for prey or as an indirect result of unique habitat and prey preferences.

It is notable that even with the potential habitat partitioning we observed, detections for all three beaked whale species were low throughout the summer. For Baird's beaked whales, this seasonal pattern does not fit with previously hypothesized distributions in the North Pacific; in Japan and California, Baird's beaked whales are presumed to move onto the continental slope during summer and then move farther offshore during the winter (Dohl et al. 1983; Balcomb 1989; Kasuya and Miyashita 1997). Meanwhile, we observed that Baird's beaked whale manual detections were highest offshore during spring, lowest during the summer, and then increased on the continental slope during the winter. It is possible that in the GoA, beaked whales are either engaged in other activities during the summer, during which they do not produce as many clicks, or they migrate farther north or south to feed or mate. Although there is still much to be learned about beaked whale ecology, this spatiotemporal distribution information for three beaked whale species can be used to inform more efficient visual and acoustic surveys of the GoA in the future.

\section{Analysis caveats}

With passive acoustic methodology comes inherent bias towards detecting animals that are actively calling. This bias is particularly pronounced for baleen whales; there is no way to determine whether they were engaging in other behaviors (or producing calls that were not selected for species identification).

Results from Stejneger's beaked whales should be interpreted with caution because, to date, there have been no documented sightings of this species with simultaneous recordings of vocalizations, which are necessary to definitively confirm that the vocalizations we recorded are in fact produced by this species. However, based on the click features and spatial occurrence, we believe that Stejneger's beaked whales are the most likely source of these clicks (Baumann-Pickering et al. 2013b, 2014). 
Automatic detection algorithms can eliminate many of the biases introduced by manual call classification, but they still have their limitations. Per-deployment optimization of the blue whale $\mathrm{B}$ call detector relies on the creation of an appropriate kernel and ground truth. For some deployments (Table S2), infrequent, sporadic calling throughout the recording period meant that it was not possible to create an adequate ground truth, and so the threshold parameter from the previous recording at the same site was used instead. Hence, we could not determine exact detector performance for those deployments either. The result is potential bias in our B call automatic detections during these time periods and, as a result, trends in B call automatic detection at Pratt may be due to changes in methodology. However, we focused discussions of interannual trends around the Slope site, which had the longest time series of data and we were able to calculate precision and recall for two out of three deployments where automatic detection was used.

The ability to compare detections across different recording locations is important when trying to understand habitat use across a region. Ideally, all data would be analyzed using methodology that allows direct comparisons between all sites, species, and call types. One of the challenges in analyzing this dataset was that it was sometimes necessary to use multiple detection methods within a species or even within a single call type, due to different noise conditions across recordings. These differences, as well as a lack of call-level information, made interpretation more challenging and prevented us from performing abundance or density estimation on these species in the GoA.

Likewise, detection area normalization for all low-frequency call types would also allow for better cross-site comparisons. Even though we calculated detection areas for all baleen whale call types (Table S5), it was only possible to normalize by detection area for certain call types when automatic detectors were used (i.e., blue whale B calls and fin whale $20-\mathrm{Hz}$ calls). For all other call types, the analysis resulted in hourly presence of a call or in total minutes of calling per week and detection area normalizations were less meaningful to apply to metrics of these call types.

\section{Conclusion}

Our findings have centered on differences in the spatial and temporal distribution within and across nine cetacean species in the GoA. There were clear seasonal patterns in calling for all mysticete species and we also found both spatial and temporal separation of calling between the calls of two blue whale populations. For odontocete species, killer whales were most common on the continental shelf, while sperm whales showed a clear preference for the continental slope. We also found evidence of potential habitat partitioning among the three beaked whale species.

The marine heat wave that created anomalous conditions in the GoA from 2013 to 2015 may be responsible for some of the results reported here, such as the decrease in blue whale calling. Analysis of data beyond 2015, as well as inclusion of regional oceanography, would be necessary to determine if any of the reported interannual changes during this period are indicative of long-term trends in species presence in the GoA, or if they were, as suggested, temporary shifts based on anomalous oceanographic conditions.

The year-round presence of most species highlights the importance of conducting continuous, long-term marine mammal surveys in a variety of different habitats in order to gain a full understanding of a species' utilization of a region. Previous studies in the GoA have been primarily visual (Consiglieri et al. 1982; Brueggeman et al. 1987, 1988; Zerbini et al. 2006; Rone et al. 2017) or focused on one habitat type (Mellinger et al. 2004a; Zerbini et al. 2006; Stafford et al. 2007; Klinck et al. 2016). While these surveys have contributed valuable information, they (including our current study) only give a part of the story if taken alone. Without acoustic surveys, we would know even less about the distributions of cryptic species such as beaked whales, or the critically endangered North Pacific right whale (Širović et al. 2015a). Without visual surveys, on the other hand, we might assume that humpback whales, for example, are not as prevalent in the GoA during summer, when vocalizations are not detected as frequently because singing is rare. Ideally, combined visual and acoustic surveys should be conducted to improve our understanding of the status of these species, some of which are considered endangered or recovering in the GoA. Long-term studies will also provide information on the ecosystem impact from changing oceanographic conditions, as we expect these species to be affected by the changing climate.

Supplementary Information The online version contains supplementary material available at https://doi.org/10.1007/s00227-021-03884-1.

Acknowledgements The authors would like to acknowledge U.S. Pacific Fleet, specifically Chip Johnson, Christiana Salles, and Jessica Bredvik, for funding and support during this study. Support was also provided by the U.S. Fish and Wildlife Service through the use of the R/V Tiglax for instrument deployment and recovery. We thank Bruce Thayre, John Hurwitz, and Ryan Griswold for coordinating instrument deployments and recoveries, Erin O'Neill for data processing, and Sarah Johnson, Arial Brewer, Leah Varga, Alba Solsona-Berga, Sara Kerosky, and Lauren Roche for contributing to data analysis. We also thank Jay Barlow and two anonymous reviewers for providing constructive feedback to improve the manuscript, as well as Marie Roch for development of the Tethys database used for storing metadata and generating figures. We acknowledge the use of the Maptool program for the generation of Fig 1; Maptool is a product of seaturtle.org. 
Authors' contributions AŠ, SMW, JAH, and SB-P contributed to the study conception, design, and management. AR, JST, AJD, and RSG performed data analysis. AS and SB-P contributed to code development and modeling for data analysis. AR generated all tables and figures. The first draft of the manuscript was written by AR. All authors commented on versions of the manuscript and read and approved the final manuscript.

Funding This study was supported by funding from the U.S. Navy's Pacific Fleet.

Availability of data and material Metadata analyzed during this study are available via the Tethys database from the corresponding author on reasonable request.

Code availability Not applicable.

\section{Declarations}

Conflict of interest This study was supported by funding from U.S. Navy's Pacific Fleet. The authors declare no conflict of interest for any aspect of this study. The authors declare that they have no conflict of interest.

Ethics approval Not applicable.

Consent to participate Not applicable.

Consent for publication Not applicable.

Open Access This article is licensed under a Creative Commons Attribution 4.0 International License, which permits use, sharing, adaptation, distribution and reproduction in any medium or format, as long as you give appropriate credit to the original author(s) and the source, provide a link to the Creative Commons licence, and indicate if changes were made. The images or other third party material in this article are included in the article's Creative Commons licence, unless indicated otherwise in a credit line to the material. If material is not included in the article's Creative Commons licence and your intended use is not permitted by statutory regulation or exceeds the permitted use, you will need to obtain permission directly from the copyright holder. To view a copy of this licence, visit http://creativecommons.org/licenses/by/4.0/.

\section{References}

Archer FI, Rankin S, Stafford KM, Castellote M, Delarue J (2020) Quantifying spatial and temporal variation of North Pacific fin whale (Balaenoptera physalus) acoustic behavior. Mar Mamm Sci 36:224-245. https://doi.org/10.1111/mms.12640

Au WWL, Mobley J, Burgess WC, Lammers MO, Nachtigall PE (2000) Seasonal and diurnal trends of chorusing humpback whales wintering in waters off western Maui. Mar Mamm Sci 16:530-544. https://doi.org/10.1111/j.1748-7692.2000.tb00949.x

Baird RW, Webster DL, Schorr GS, McSweeney DJ, Barlow J (2008) Diel variation in beaked whale diving behavior. Mar Mamm Sci 24:630-642. https://doi.org/10.1111/j.1748-7692.2008.00211.x

Balcomb KC III (1851) Baird's beaked whale - Berardius bairdii Stejneger, 1883: Arnoux's beaked whale-Berardius arnuxii Duvernoy, 1851. In: Ridgway SH, Harrison R (eds) Handbook of marine mammals Volume 4: river dolphins and the larger toothed whales. Academic Press, London, pp 261-288

Barlow J, Calambokidis J, Falcone EA, Baker CS, Burdin AM, Clapham PJ, Ford JKB, Gabriele CM, LeDuc R, Mattila DK, Quinn TJ, Rojas-Bracho L, Straley JM, Taylor BL, Urban J, Wade P, Weller D, Witteveen BH, Yamaguchi M (2011) Humpback whale abundance in the North Pacific estimated by photographic capture-recapture with bias correction from simulation studies. Mar Mamm Sci 27:793-818. https://doi.org/10.1111/j. 1748-7692.2010.00444.x

Barlow J, Ferguson MC, Perrin WF, Ballance L, Gerrodette T, Joyce G, MacLeod CD, Mullin K, Palka DL, Waring G (2005) Abundance and densities of beaked and bottlenose whales (family Ziphiidae). J Cetacean Res Manag 7:263-270

Barrett-Lennard L (2000) Population structure and mating patterns of killer whales as revealed by DNA analysis. Dissertation, University of British Columbia

Barrett-Lennard LG, Ford JKB, Heise KA (1996) The mixed blessing of echolocation: differences in sonar use by fish-eating and mammal-eating killer whales. Anim Behav 51:553-565. https://doi.org/10.1006/anbe.1996.0059

Baumann-Pickering S, McDonald MA, Simonis AE, Berga AS, Merkens KPB, Oleson EM, Roch MA, Wiggins SM, Rankin S, Yack TM, Hildebrand JA (2013a) Species-specific beaked whale echolocation signals. J Acoust Soc Am 134:2293-2301. https://doi.org/10.1121/1.4817832

Baumann-Pickering S, Roch MA, Brownell RL, Simonis AE, McDonald MA, Solsona-Berga A, Oleson EM, Wiggins SM, Hildebrand JA (2014) Spatio-temporal patterns of beaked whale echolocation signals in the North Pacific. PLoS ONE 9:17. https://doi.org/10.1371/journal.pone.0086072

Baumann-Pickering S, Simonis AE, Wiggins SM, Brownell RL, Hildebrand JA (2013b) Aleutian Islands beaked whale echolocation signals. Mar Mamm Sci 29:221-227. https://doi.org/ 10.1111/j.1748-7692.2011.00550.x

Baumann-Pickering S, Trickey JS, Wiggins SM, Oleson EM (2016) Odontocete occurrence in relation to changes in oceanography at a remote equatorial Pacific seamount. Mar Mamm Sci 32:805-825. https://doi.org/10.1111/mms.12299

Baumann-Pickering S, Yack TM, Barlow J, Wiggins SM, Hildebrand JA (2013c) Baird's beaked whale echolocation signals. J Acoust Soc Am 133:4321-4331. https://doi.org/10.1121/1. 4804316

Berube M, Urban J, Dizon AE, Brownell RL, Palsboll PJ (2002) Genetic identification of a small and highly isolated population of fin whales (Balaenoptera physalus) in the Sea of Cortez, Mexico. Conserv Genet 3:183-190. https://doi.org/10.1023/a: 1015224730394

Bond NA, Cronin MF, Freeland H, Mantua N (2015) Causes and impacts of the 2014 warm anomaly in the NE Pacific. Geophys Res Lett 42:3414-3420. https://doi.org/10.1002/2015g1063306

Brodeur RD, Auth TD, Phillips AJ (2019) Major Shifts in Pelagic Micronekton and Macrozooplankton Community Structure in an Upwelling Ecosystem Related to an Unprecedented Marine Heatwave. Front Mar Sci 6:15. https://doi.org/10.3389/fmars. 2019.00212

Brueggeman JJ, Green GA, Grotefendt RA, Chapman DG (1987) Aerial surveys of endangered cetaceans and other marine mammals in the northwestern Gulf of Alaska and southeastern Bering Sea. Final Report: Outer Continental Shelf Environmental Assessment Program, Research Unit 673. Bellevue, Washington: Envirosphere Company

Brueggeman JJ, Green GA, Tressler RW, Chapman DG (1988) Shipboard surveys of endangered cetaceans in the northwestern Gulf of Alaska. Final Report: Outer Continental Shelf Environmental 
Assessment Program, Research Unit 673. Bellevue, Washington: Envirosphere Company

Burnham RE, Duffus DA (2020) Maternal behaviors of gray whales (Eschrichtius robustus) on a summer foraging site. Mar Mamm Sci 36:1212-1230. https://doi.org/10.1111/mms.12710

Calambokidis J, Barlow J, Ford JKB, Chandler TE, Douglas AB (2009) Insights into the population structure of blue whales in the Eastern North Pacific from recent sightings and photographic identification. Mar Mamm Sci 25:816-832. https://doi.org/10.1111/j. 1748-7692.2009.00298.x

Calambokidis J, Darling JD, Deecke V, Gearin P, Gosho M, Megill W, Tombach CM, Goley D, Toropova C, Gisborne B (2002) Abundance, range and movements of a feeding aggregation of gray whales (Eschrichtius robustus) from California to southeastern Alaska in 1998. J Cetacean Res Manage 4:267-276

Carone E, Pardo MA, Atkinson S, Mashburn K, Perez-Puig H, Enriquez-Paredes L, Gendron D (2019) Sex steroid hormones and behavior reveal seasonal reproduction in a resident fin whale population. Conserv Physiol 7:13. https://doi.org/10.1093/conph ys/coz059

Cates KA, Atkinson S, Gabriele CM, Pack AA, Straley JM, Yin S (2019) Testosterone trends within and across seasons in male humpback whales (Megaptera novaeangliae) from Hawaii and Alaska. Gen Comp Endocrinol 279:164-173. https://doi.org/10. 1016/j.ygcen.2019.03.013

Cavole LM, Demko AM, Diner RE, Giddings A, Koester I, Pagniello C, Paulsen ML, Ramirez-Valdez A, Schwenck SM, Yen NK, Zill ME, Franks PJS (2016) Biological impacts of the 2013-2015 warm-water anomaly in the Northeast Pacific: winners, losers, and the future. Oceanography 29:273-285. https://doi.org/10. 5670/oceanog.2016.32

Clapham PJ, Mattila DK (1990) Humpback whale songs as indicators of migration routes. Mar Mamm Sci 6:155-160. https://doi.org/ 10.1111/j.1748-7692.1990.tb00238.x

Clark CW (1982) The acoustic repertoire of the Southern right whale, a quantitative analysis. Anim Behav 30:1060-1071. https://doi. org/10.1016/s0003-3472(82)80196-6

Clark CW, Clapham PJ (2004) Acoustic monitoring on a humpback whale (Megaptera novaeangliae) feeding ground shows continual singing into late spring. Proc R Soc B 271:1051-1057. https:// doi.org/10.1098/rspb.2004.2699

Clarke MR, Martins HR, Pascoe P (1993) The diet of sperm whales (Physeter macrocephalus Linnaeus 1758) off the Azores. Philos Trans R Soc Lond Ser B-Biol Sci 339:67-82. https://doi.org/10. 1098/rstb.1993.0005

Consiglieri LD, Braham HW, Dahlheim ME, Fiscus C, McGuire PD, Peterson CE, Pippenger DA (1982) Seasonal distribution and relative abundance of marine mammals in the Gulf of Alaska. Final Report: Outer Continental Shelf Environmental Assessment Program, Research Unit 68. Seattle, Washington: National Marine Mammal Laboratory, Northwest and Alaska Fisheries Center

Crance JL, Berchok CL, Keating JL (2017) Gunshot call production by the North Pacific right whale Eubalaena japonica in the southeastern Bering Sea. Endanger Species Res 34:251-267. https:// doi.org/10.3354/esr00848

Crane NL, Lashkari K (1996) Sound production of gray whales, Eschrichtius robustus, along their migration route: a new approach to signal analysis. J Acoust Soc Am 100:1878-1886. https://doi.org/10.1121/1.416006

Croll DA, Clark CW, Acevedo A, Tershy B, Flores S, Gedamke J, Urban J (2002) Only male fin whales sing loud songs. Nature 417:809-809. https://doi.org/10.1038/417809a

Dahlheim ME (1987) Bio-acoustics of the gray whale (Eschirchtius robustus). Dissertation, University of British Columbia
Dahlheim ME, Schulman-Janiger A, Black N, Ternullo R, Ellifrit D, Balcomb KC (2008) Eastern temperate North Pacific offshore killer whales (Orcinus orca): occurrence, movements, and insights into feeding ecology. Mar Mamm Sci 24:719-729. https://doi.org/10.1111/j.1748-7692.2008.00206.x

Danner EM, Kauffman MJ, Brownell RL (2006) Industrial whaling in the North Pacific Ocean 1952-1978 spatial patterns of harvest and decline. In: Estes JA, Demaster DP, Doak DF, Williams TM, Brownell RL (eds) Whales, whaling, and ocean ecosystems. Univ California Press, Berkeley, pp 134-144

Davis GE, Baumgartner MF, Corkeron PJ, Bell J, Berchok C, Bonnell JM, Thornton JB, Brault S, Buchanan GA, Cholewiak DM, Clark CW, Delarue J, Hatch LT, Klinck H, Kraus SD, Martin B, Mellinger DK, Moors-Murphy H, Nieukirk S, Nowacek DP, Parks SE, Parry D, Pegg N, Read AJ, Rice AN, Risch D, Scott A, Soldevilla MS, Stafford KM, Stanistreet JE, Summers E, Todd S, Van Parijs SM (2020) Exploring movement patterns and changing distributions of baleen whales in the western North Atlantic using a decade of passive acoustic data. Glob Change Biol 26:4812-4840. https://doi.org/10.1111/gcb.15191

Dawson S, Barlow J, Ljungblad D (1998) Sounds recorded from Baird's beaked whale, Berardius bairdii. Mar Mamm Sci 14:335-344. https://doi.org/10.1111/j.1748-7692.1998.tb00724.x

Deecke VB, Ford JKB, Slater PJB (2005) The vocal behaviour of mammal-eating killer whales: communicating with costly calls. Anim Behav 69:395-405. https://doi.org/10.1016/j.anbehav. 2004.04.014

Diogou N, Palacios DM, Nieukirk SL, Nystuen JA, Papathanassiou E, Katsanevakis S, Klinck H (2019) Sperm whale (Physeter macrocephalus) acoustic ecology at Ocean Station PAPA in the Gulf of Alaska-Part 1: detectability and seasonality. Deep-Sea Res Part I-Oceanogr Res Pap 150:14. https://doi.org/10.1016/j.dsr. 2019.05.007

Dohl TP, Guess RC, Dunman ML, R.C. H (1983) Cetaceans of central and northern California, 1980-1983: Status, abundance, and distribution. Prepared for Pacific OCS Region, NMS 84-0045, US Department of Interior

Dunlop RA, Noad MJ, Cato DH, Stokes D (2007) The social vocalization repertoire of east Australian migrating humpback whales (Megaptera novaeangliae). J Acoust Soc Am 122:2893-2905. https://doi.org/10.1121/1.2783115

Espanol-Jimenez S, van der Schaar M (2018) First record of humpback whale songs in Southern Chile: analysis of seasonal and diel variation. Mar Mamm Sci 34:718-733. https://doi.org/10.1111/ mms. 12477

Evans K, Hindell MA (2004) The diet of sperm whales (Physeter macrocephalus) in southern Australian waters. ICES J Mar Sci 61:1313-1329. https://doi.org/10.1016/j.icesjms.2004.07.026

Fearnbach HD, J.W., Mizroch SA, Barbeaux S, Wade PR, (2012) Winter observations of a group of female and immature sperm whales in the high-latitude waters near the Aleutian Islands, Alaska. Mar Biodivers Rec 5:1-4. https://doi.org/10.1017/S175526721 1001047

Ferguson MC, Curtice C, Harrison J (2015) Biologically important areas for cetaceans within US waters-Gulf of Alaska region. Aquat Mamm 41:65-78. https://doi.org/10.1578/am.41.1.2015. 65

Filatova OA, Ford JKB, Matkin CO, Barrett-Lennard LG, Burdin AM, Hoyt E (2012) Ultrasonic whistles of killer whales (Orcinus orca) recorded in the North Pacific. J Acoust Soc Am 132:36183621. https://doi.org/10.1121/1.4764874

Fisher J, Trudel M, Ammann A, Orsi JA, Piccolo J, Bucher C, Casillas E, Harding JA, Macfarlane RB, Brodeur RD, Morris JFT, Welch DW (2007) Comparisons of the coastal distributions and abundances of juvenile Pacific salmon from central California to the Northern Gulf of Alaska. Am Fish Soc Symp 57:31 
Ford JKB (1989) Acoustic behavior of resident killer whales (Orcinus orca) off Vancouver Island, British Columbia. Can J Zool 67:727-745. https://doi.org/10.1139/z89-105

Ford JKB (1991) Vocal traditions among resident killer whales (Orcinus orca) in coastal waters of British Columbia. Can J Zool 69:1454-1483. https://doi.org/10.1139/z91-206

Ford JKB, Ellis GM (2006) Selective foraging by fish-eating killer whales Orcinus orca in British Columbia. Mar Ecol Prog Ser 316:185-199. https://doi.org/10.3354/meps316185

Ford JKB, Ellis GM, Barrett-Lennard LG, Morton AB, Palm RS, Balcomb KC (1998) Dietary specialization in two sympatric populations of killer whales (Orcinus orca) in coastal British Columbia and adjacent waters. Can J Zool 76:1456-1471. https://doi.org/ 10.1139/cjz-76-8-1456

Ford JKB, Stredulinsky EH, Ellis GM, Durban JW, Pilkington JF (2014) Offshore killer whales in Canadian Pacific waters: Distribution, seasonality, foraging ecology, population status and potential for recovery. Canadian Science Advisory Secretariat Research Document 88: i-vi, 1-55

Forney KA, Barlow J (1998) Seasonal patterns in the abundance and distribution of California cetaceans, 1991-1992. Mar Mamm Sci 14:460-489. https://doi.org/10.1111/j.1748-7692.1998.tb00737.x

Fournet ME, Szabo A, Mellinger DK (2015) Repertoire and classification of non-song calls in Southeast Alaskan humpback whales (Megaptera novaeangliae). J Acoust Soc Am 137:1-10. https:// doi.org/10.1121/1.4904504

Fournet MEH, Matthews LP, Gabriele CM, Haver S, Mellinger DK, Klinck H (2018a) Humpback whales Megaptera novaeangliae alter calling behavior in response to natural sounds and vessel noise. Mar Ecol Prog Ser 607:251-268. https://doi.org/10.3354/ meps 12784

Fournet MEH, Matthews LP, Gabriele CM, Mellinger DK, Klinck H (2018) Source levels of foraging humpback whale calls. J Acoust Soc Am 143:EL105-EL111. https://doi.org/10.1121/1.5023599

Gabriele CM, Frankel AS (2002) The occurrence and significance of humpback whale songs in Glacier Bay, Southeastern Alaska. Arctic Res 16:42-47

Gabriele CM, Neilson JL, Straley JM, Baker CS, Cedarleaf JA, Saracco JF (2017) Natural history, population dynamics, and habitat use of humpback whales over 30 years on an Alaska feeding ground. Ecosphere 8:18. https://doi.org/10.1002/ecs2.1641

Garland EC, Gedamke J, Rekdahl ML, Noad MJ, Garrigue C, Gales N (2013) Humpback whale song on the Southern Ocean feeding grounds: implications for cultural transmission. PLoS ONE 8:9. https://doi.org/10.1371/journal.pone.0079422

Garrigue C, Clapham PJ, Geyer Y, Kennedy AS, Zerbini AN (2015) Satellite tracking reveals novel migratory patterns and the importance of seamounts for endangered South Pacific humpback whales. R Soc Open Sci 2:11. https://doi.org/10.1098/rsos. 150489

Gassmann M, Henderson EE, Wiggins SM, Roch MA, Hildebrand JA (2013) Offshore killer whale tracking using multiple hydrophone arrays. J Acoust Soc Am 134:3513-3521. https://doi.org/ $10.1121 / 1.4824162$

Goldbogen JA, Friedlaender AS, Calambokidis J, McKenna MF, Simon M, Nowacek DP (2013) Integrative approaches to the study of baleen whale diving behavior, feeding performance, and foraging ecology. Bioscience 63:90-100. https://doi.org/10.1525/bio. 2013.63.2.5

Goold JC, Jones SE (1995) Time and frequency domain characteristics of sperm whale clicks. J Acoust Soc Am 98:1279-1291. https:// doi.org/10.1121/1.413465

Gregr EJ, Nichol L, Ford JKB, Ellis G, Trites AW (2000) Migration and population structure of northeastern Pacific whales off coastal British Columbia: an analysis of commercial whaling records from 1908-1967. Mar Mamm Sci 16:699-727. https:// doi.org/10.1111/j.1748-7692.2000.tb00967.x

Hann CH, Smith TD, Torres LG (2016) A sperm whale's perspective: the importance of seasonality and seamount depth. Mar Mamm Sci 32:1470-1481. https://doi.org/10.1111/mms.12320

Heise K, Barrett-Lennard L, Ford JKB, Ellis G (1993) Killer whales of the Queen Charlotte Islands: Results of research on the abundance, distribution, and population identity of Orcinus orca in the waters of Haida Gwaii in 1992. Prepared for South Maresby/ Gwaii Haanas National Park Reserve, Canadian Parks Service, Queen Charlotte City, BC

Helble TA (2013) Site specific passive acoustic detection and densities of humpback whale calls off the coast of California. Dissertation, University of California, San Diego

Helble TA, D'Spain GL, Campbell GS, Hildebrand JA (2013) Calibrating passive acoustic monitoring: Correcting humpback whale call detections for site-specific and time-dependent environmental characteristics. J Acoust Soc Am 134:EL400EL406. https://doi.org/10.1121/1.4822319

Helble TA, Ierley GR, D'Spain GL, Roch MA, Hildebrand JA (2012) A generalized power-law detection algorithm for humpback whale vocalizations. J Acoust Soc Am 131:2682-2699. https:// doi.org/10.1121/1.3685790

Helweg DA, Herman LM (1994) Diurnal patterns of behavior and group membership of humpback whales ( Megaptera novaeangliae ) wintering in Hawaiian waters. Ethology 98:298-311. https://doi.org/10.1111/j.1439-0310.1994.tb01078.x

Henderson EE, Helble TA, Ierley GR, Martin SW (2018) Identifying behavioral states and habitat use of acoustically tracked humpback whales in Hawaii. Mar Mamm Sci 34:1-17. https:// doi.org/10.1111/mms. 12475

Hoelzel AR, Dahlheim M, Stern SJ (1998) Low genetic variation among killer whales (Orcinus orca) in the eastern North Pacific and genetic differentiation between foraging specialists. J Hered 89:121-128

Huang W, Wang DL, Ratilal P (2016) Diel and spatial dependence of humpback song and non-song vocalizations in fish spawning ground. Remote Sens 8:22. https://doi.org/10.3390/rs8090712

Hunt KE, Lysiak NS, Matthews CJD, Lowe C, Ajo AF, Dillon D, Willing C, Heide-Jorgensen MP, Ferguson SH, Moore MJ, Buck CL (2018) Multi-year patterns in testosterone, cortisol and corticosterone in baleen from adult males of three whale species. Conserv Physiol 6:16. https://doi.org/10.1093/conph ys/coy049

Ivashchenko YV, Brownell RL, Clapham PJ (2014) Distribution of Soviet catches of sperm whales Physeter macrocephalus in the North Pacific. Endanger Species Res 25:249-263. https://doi. org/10.3354/esr00641

Ivashchenko YV, Clapham PJ (2015) What's the catch? Validity of whaling data for Japanese catches of sperm whales in the North Pacific. R Soc Open Sci 2:8. https://doi.org/10.1098/rsos.150177

Johnson M, Madsen PT, Zimmer WMX, de Soto NA, Tyack PL (2004) Beaked whales echolocate on prey. Proc R Soc B-Biol Sci 271:S383-S386. https://doi.org/10.1098/rsbl.2004.0208

Kasuya T, Miyashita T (1997) Distribution of Baird's beaked whales off Japan. Rep Int Whal Comm 47:963-968

Kawakami T (1980) A review of sperm whale Physeter macrocephalus food. Sci Rep Whales Res Inst Tokyo: 199-218

Kjeld M, Olafsson O, Vikingsson GA, Sigurjonsson J (2006) Sex hormones and reproductive status of the North Atlantic fin whales (Balaenoptera physalus) during the feeding season. Aquat Mamm 32:75-84. https://doi.org/10.1578/AM.32.1.2006.75

Klinck H, Nieukirk SL, Fregosi S, Klinck K, Mellinger DK, Lastuka S, Shilling GB, Luby JC (2016) Cetacean studies in the Gulf of Alaska Temporary Maritime Activities Area in July-August 2015: Passive acoustic monitoring of marine mammals using 
gliders. Prepared for Commander, U.S. Pacific Fleet, Environmental Readiness Division, Pearl Harbor, HI. Submitted to Naval Facilities Engineering Command (NAVFAC) Pacific, Pearl Harbor, Hawaii under Contract No. N62470-10-D-3011, Task Order KB25, issued to HDR Inc., Honolulu, Hawaii. March 2016.

Kowarski K, Evers C, Moors-Murphy H, Martin B, Denes SL (2018) Singing through winter nights: seasonal and diel occurrence of humpback whale (Megaptera novaeangliae) calls in and around the Gully MPA, offshore eastern Canada. Mar Mamm Sci 34:169-189. https://doi.org/10.1111/mms.12447

Kowarski KA, Moors-Murphy H (2020) A review of big data analysis methods for baleen whale passive acoustic monitoring. Mar Mamm Sci 1-22

Larson WA, Utter FM, Myers KW, Templin WD, Seeb JE, Guthrie CM, Bugaev AV, Seeb LW (2013) Single-nucleotide polymorphisms reveal distribution and migration of Chinook salmon (Oncorhynchus tshawytscha) in the Bering Sea and North Pacific Ocean. Can J Fish Aquat Sci 70:128-141. https://doi.org/10.1139/ cjfas-2012-0233

Leroy EC, Samaran F, Bonnel J, Royer JY (2016) Seasonal and diel vocalization patterns of Antarctic blue whale (Balaenoptera musculus intermedia) in the Southern Indian Ocean: a multi-year and multi-site study. PLoS ONE 11:20. https://doi.org/10.1371/journ al.pone. 0163587

Lewis LA, Calambokidis J, Stimpert AK, Fahlbusch J, Friedlaender AS, McKenna MF, Mesnick SL, Oleson EM, Southall BL, Szesciorka AR, Širović A (2018) Context-dependent variability in blue whale acoustic behaviour. R Soc Open Sci 5:20. https://doi. org/10.1098/rsos.180241

Loughlin TR, Perez MA (1985) Mesoplodon stejnegeri. Mamm Species. https://doi.org/10.2307/3503801

MacLeod CD, Santos MB, Pierce GJ (2003) Review of data on diets of beaked whales: evidence of niche separation and geographic segregation. J Mar Biol Assoc UK 83:651-665. https://doi.org/ 10.1017/S0025315403007616h

Madsen PT, Wahlberg M, Mohl B (2002) Male sperm whale (Physeter macrocephalus) acoustics in a high-latitude habitat: implications for echolocation and communication. Behav Ecol Sociobiol 53:31-41. https://doi.org/10.1007/s00265-002-0548-1

Mate BR, Ilyashenko VY, Bradford AL, Vertyankin VV, Tsidulko GA, Rozhnov VV, Irvine LM (2015) Critically endangered western gray whales migrate to the eastern North Pacific. Biol Lett 11:4. https://doi.org/10.1098/rsbl.2015.0071

Mathias D, Thode AM, Straley J, Calambokidis J, Schorr GS, Folkert K (2012) Acoustic and diving behavior of sperm whales (Physeter macrocephalus) during natural and depredation foraging in the Gulf of Alaska. J Acoust Soc Am 132:518-532. https://doi.org/ $10.1121 / 1.4726005$

McDonald MA, Calambokidis J, Teranishi AM, Hildebrand JA (2001) The acoustic calls of blue whales off California with gender data. J Acoust Soc Am 109:1728-1735. https://doi.org/10.1121/1. 1353593

McDonald MA, Hildebrand JA, Mesnick S (2009) Worldwide decline in tonal frequencies of blue whale songs. Endanger Species Res 9:13-21. https://doi.org/10.3354/esr00217

McDonald MA, Mesnick SL, Hildebrand JA (2006) Biogeographic characterisation of blue whale song worldwide: using song to identify populations. J Cetacean Res Manag 8:55-65

McDonald MA, Moore SE (2002) Calls recorded from North Pacific right whales (Eubalaena japonica) in the Eastern Bering Sea. J Cetacean Res Manag 4:261-266

McSweeney DJ, Chu KC, Dolphin WF, Guinee LN (1989) North Pacific humpback whale songs: a comparison of Southeast Alaskan feeding ground songs with Hawaiian wintering ground songs. Mar Mamm Sci 5:139-148. https://doi.org/10.1111/j. 1748-7692.1989.tb00328.x
Mellinger DK, Clark CW (2000) Recognizing transient low-frequency whale sounds by spectrogram correlation. J Acoust Soc Am 107:3518-3529. https://doi.org/10.1121/1.429434

Mellinger DK, Clark CW (2003) Blue whale (Balaenoptera musculus) sounds from the North Atlantic. J Acoust Soc Am 114:11081119. https://doi.org/10.1121/1.1593066

Mellinger DK, Stafford KM, Fox CG (2004) Seasonal occurrence of sperm whale (Physeter macrocephalus) sounds in the Gulf of Alaska, 1999-2001. Mar Mamm Sci 20:48-62. https://doi.org/ 10.1111/j.1748-7692.2004.tb01140.x

Mellinger DK, Stafford KM, Moore SE, Munger U, Fox CG (2004) Detection of North Pacific right whale (Eubalaena japonica) calls in the Gulf of Alaska. Mar Mamm Sci 20:872-879. https:// doi.org/10.1111/j.1748-7692.2004.tb01198.x

Mitchell E (1968) Northeast Pacific stranding distribution and seasonality of Cuvier's beaked whale Ziphius cavirostris. Can J Zool 46:265. https://doi.org/10.1139/z68-040

Mizroch SA, Rice DW, Zwiefelhofer D, Waite J, Perryman WL (2009) Distribution and movements of fin whales in the North Pacific Ocean. Mamm Rev 39:193-227. https://doi.org/10.1111/j.13652907.2009.00147.x

Monnahan CC, Branch TA, Punt AE (2015) Do ship strikes threaten the recovery of endangered Eastern North Pacific blue whales? Mar Mamm Sci 31:279-297. https://doi.org/10.1111/mms.12157

Moore SE, Wynne KM, Kinney JC, Grebmeier JM (2007) Gray whale occurrence and forage southeast of Kodiak, Island, Alaska. Mar Mamm Sci 23:419-428. https://doi.org/10.1111/j.1748-7692. 2007.00102.x

Muto MM, Helker VT, Angliss RP, Boveng PL, Breiwick JM, Cameron MF, Clapham PJ, Dahle SP, Dahlheim ME, Fadely BS, Ferguson MC, Fritz LW, Hobbs RC, Ivashchenko YV, Kennedy AS, London JM, Mizroch SA, Ream RR, Richmond EL, Shelden KEW, Sweeney KL, Towell RG, Wade PR, Waite JM, Zerbini AN (2019) Alaska Marine Mammal Stock Assessments, 2018. NOAA Technical Memorandum NMFS-AFSC 393: i-v, 1-390

Møhl B, Wahlberg M, Madsen PT, Heerfordt A, Lund A (2003) The monopulsed nature of sperm whale clicks. J Acoust Soc Am 114:1143-1154. https://doi.org/10.1121/1.1586258

Nemoto T, Kawamura A (1977) Characteristics of food habits and distribution of baleen whales with special reference to the abundance of North Pacific sei and bryde's whales. Int Whal Comm Rep Comm: 80-87

Nieukirk SL, Mellinger DK, Moore SE, Klinck K, Dziak RP, Goslin J (2012) Sounds from airguns and fin whales recorded in the midAtlantic Ocean, 1999-2009. J Acoust Soc Am 131:1102-1112. https://doi.org/10.1121/1.3672648

Nishiwaki M, Oguro N (1971) Baird's beaked whales caught on the coast of Japan in recent 10 years. Sci Rep Whales Res Inst Tokyo No 23(1971):111-122

NMFS (1994) Endangered and threatened wildlife and plant; Final rule to remove the eastern North Pacific population of the gray whale from the list of endangered wildlife. Fed Reg 59:31094-31095

NOAA (2016) Endangered and threatened species; Identification of 14 distinct populations segments of the humpback whale ( $\mathrm{Meg}$ aptera novaeangliae) and revision of species-wide listing. Fed Reg 81:62260-62320

Norris TF, Mc Donald M, Barlow J (1999) Acoustic detections of singing humpback whales (Megaptera novaeangliae) in the eastern North Pacific during their northbound migration. J Acoust Soc Am 106:506-514. https://doi.org/10.1121/1.427071

Okutani T, Nemoto T (1964) Squids as the food of sperm whales in the Bering Sea and Alaskan Gulf. Sci Rep Whales Res Inst 18:111-121

Oleson EM, Calambokidis J, Burgess WC, McDonald MA, LeDuc CA, Hildebrand JA (2007) Behavioral context of call production by 
eastern North Pacific blue whales. Mar Ecol Prog Ser 330:269284. https://doi.org/10.3354/meps330269

Oleson EM, Slrovic A, Bayless AR, Hildebrand JA (2014) Synchronous seasonal change in fin whale song in the North Pacific. PLoS ONE 9:18. https://doi.org/10.1371/journal.pone.0115678

Oleson EM, Wiggins SM, Hildebrand JA (2007) Temporal separation of blue whale call types on a southern California feeding ground. Anim Behav 74:881-894. https://doi.org/10.1016/j. anbehav.2007.01.022

Payne RS, McVay S (1971) Songs of humpback whales. Science 173:585-597. https://doi.org/10.1126/science.173.3997.585

Pena MA, Nemcek N, Robert M (2019) Phytoplankton responses to the 2014-2016 warming anomaly in the northeast subarctic Pacific Ocean. Limnol Oceanogr 64:515-525. https://doi.org/10.1002/ lno.11056

Peterson WT, Fisher JL, Strub PT, Du XN, Risien C, Peterson J, Shaw CT (2017) The pelagic ecosystem in the Northern California Current off Oregon during the 2014-2016 warm anomalies within the context of the past 20 years. J Geophys Res-Oceans 122:7267-7290. https://doi.org/10.1002/2017jc012952

R Core Team (2020) R: a language and environment for statistical computing. R Foundation for Statistical Computing, Vienna

Rankin S, Ljungblad D, Clark C, Kato H (2005) Vocalisations of Antarctic blue whales, Balaenoptera musculus intermedia, recorded during the 2001/2002, and 2002/2003 IWC/SOWER circumpolar cruises, Area V, Antarctica. J Cetacean Res Manag 7:13-20

Rekdahl M, Tisch C, Cerchio S, Rosenbaum H (2017) Common nonsong social calls of humpback whales (Megaptera novaeangliae) recorded off northern Angola, southern Africa. Mar Mamm Sci 33:365-375. https://doi.org/10.1111/mms.12355

Rice DW, Wolman AA (1971) The life history and ecology of the gray whale (Eschrichtius robustus). Spec Publ Am Soc Mammal No 3:1-142

Roch MA, Klinck H, Baumann-Pickering S, Mellinger DK, Qui S, Soldevilla MS, Hildebrand JA (2011) Classification of echolocation clicks from odontocetes in the Southern California Bight. J Acoust Soc Am 129:467-475. https://doi.org/10.1121/1.3514383

Rocha RC Jr, Clapham PJ, Ivashchenko YV (2014) Emptying the oceans: a summary of industrial whaling catches in the 20th century. US National Marine Fisheries Service Marine Fisheries Review 76:37-48

Rone BK, Zerbini AN, Douglas AB, Weller DW, Clapham PJ (2017) Abundance and distribution of cetaceans in the Gulf of Alaska. Mar Biol 164:23. https://doi.org/10.1007/s00227-016-3052-2

Ryan JP, Cline DE, Joseph JE, Margolina T, Santora JA, Kudela RM, Chavez FP, Pennington JT, Wahl C, Michisaki R, Benoit-Bird K, Forney KA, Stimpert AK, DeVogelaere A, Black N, Fischer M (2019) Humpback whale song occurrence reflects ecosystem variability in feeding and migratory habitat of the Northeast Pacific. PLoS ONE 14:24. https://doi.org/10.1371/journal.pone.0222456

Samarra FIP, Deecke VB, Vinding K, Rasmussen MH, Swift RJ, Miller PJO (2010) Killer whales (Orcinus orca) produce ultrasonic whistles. J Acoust Soc Am 128:EL205-EL210. https://doi.org/ 10.1121/1.3462235

Saulitis E, Matkin C, Barrett-Lennard L, Heise K, Ellis G (2000) Foraging strategies of sympatric killer whale (Orcinus orca) populations in Prince William Sound, Alaska. Mar Mamm Sci 16:94-109. https://doi.org/10.1111/j.1748-7692.2000.tb00906.x

Saulitis EL, Matkin CO, Fay FH (2005) Vocal repertoire and acoustic behavior of the isolated AT1 killer whale subpopulation in southern Alaska. Can J Zool Rev Can Zool 83:1015-1029. https://doi. org/10.1139/z05-089

Savage K (2017) Alaska and British Columbia large whale unusual mortality event summary report. NOAA Fisheries Protected Resources Division, Juneau
Schorr GS, Falcone EA, Moretti DJ, Andrews RD (2014) First longterm behavioral records from Cuvier's beaked whales (Ziphius cavirostris) reveal record-breaking dives. PLoS ONE 9:10. https://doi.org/10.1371/journal.pone.0092633

Sharpe DL, Castellote M, Wade PR, Cornick LA (2017) Call types of Bigg's killer whales (Orcinus orca) in western Alaska: using vocal dialects to assess population structure. Bioacoustics 28:7499. https://doi.org/10.1080/09524622.2017.1396562

Shearer JM, Quick NJ, Cioffi WR, Baird RW, Webster DL, Foley HJ, Swaim ZT, Waples DM, Bell JT, Read AJ (2019) Diving behaviour of Cuvier's beaked whales (Ziphius cavirostris) off Cape Hatteras. North Carolina R Soc Open Sci 6:21. https://doi.org/ 10.1098/rsos. 181728

Simon M, Johnson M, Madsen PT (2012) Keeping momentum with a mouthful of water: behavior and kinematics of humpback whale lunge feeding. J Exp Biol 215:3786-3798. https://doi.org/10. 1242/jeb.071092

Simonis AE, Baumann-Pickering S, Oleson E, Melcon ML, Gassmann M, Wiggins SM, Hildebrand JA (2012) High-frequency modulated signals of killer whales (Orcinus orca) in the North Pacific. J Acoust Soc Am 131:EL295-EL301. https:// doi.org/10.1121/1.3690963

Širović A (2016) Variability in the performance of the spectrogram correlation detector for North-east Pacific blue whale calls. Bioacoustics 25:145-160. https://doi.org/10.1080/09524622. 2015.1124248

Širović A, Hildebrand JA, Wiggins SM, McDonald MA, Moore SE, Thiele D (2004) Seasonality of blue and fin whale calls and the influence of sea ice in the Western Antarctic Peninsula. DeepSea Res Part II-Top Stud Oceanogr 51:2327-2344. https://doi. org/10.1016/j.dsr2.2004.08.005

Širović A, Johnson SC, Roche LK, Varga LM, Wiggins SM, Hildebrand JA (2015) North Pacific right whales (Eubalaena japonica) recorded in the northeastern Pacific Ocean in 2013. Mar Mamm Sci 31:800-807. https://doi.org/10.1111/mms.12189

Širović A, Oleson EM, Buccowich J, Rice A, Bayless AR (2017) Fin whale song variability in southern California and the Gulf of California. Sci Rep 7:10126. https://doi.org/10.1038/ s41598-017-09979-4

Širović A, Rice A, Chou E, Hildebrand JA, Wiggins SM, Roch MA (2015) Seven years of blue and fin whale call abundance in the Southern California Bight. Endanger Species Res 28:61-76. https://doi.org/10.3354/esr00676

Širović A, Williams LN, Kerosky SM, Wiggins SM, Hildebrand JA (2013) Temporal separation of two fin whale call types across the eastern North Pacific. Mar Biol 160:47-57. https://doi.org/ 10.1007/s00227-012-2061-z

Soldevilla MS, Henderson EE, Campbell GS, Wiggins SM, Hildebrand JA, Roch MA (2008) Classification of Risso's and Pacific white-sided dolphins using spectral properties of echolocation clicks. J Acoust Soc Am 124:609-624. https://doi.org/10. $1121 / 1.2932059$

Stabeno PJ, Bond NA, Hermann AJ, Kachel NB, Mordy CW, Overland JE (2004) Meteorology and oceanography of the Northern Gulf of Alaska. Cont Shelf Res 24:859-897. https://doi.org/10.1016/j. csr.2004.02.007

Stafford KM (2003) Two types of blue whale calls recorded in the Gulf of Alaska. Mar Mamm Sci 19:682-693. https://doi.org/10.1111/j. 1748-7692.2003.tb01124.x

Stafford KM, Mellinger DK, Moore SE, Fox CG (2007) Seasonal variability and detection range modeling of baleen whale calls in the Gulf of Alaska, 1999-2002. J Acoust Soc Am 122:3378-3390. https://doi.org/10.1121/1.2799905

Stafford KM, Moore SE, Fox CG (2005) Diel variation in blue whale calls recorded in the eastern tropical Pacific. Anim Behav 69:951-958. https://doi.org/10.1016/j.anbehav.2004.06.025 
Stafford KM, Nieukirk SL, Fox CG (2001) Geographic and seasonal variation of blue whale calls in the North Pacific. J Cetacean Res Manag 3:65-76

Stimpert AK, Au WWL, Parks SE, Hurst T, Wiley DN (2011) Common humpback whale (Megaptera novaeangliae) sound types for passive acoustic monitoring. J Acoust Soc Am 129:476-482. https:// doi.org/10.1121/1.3504708

Stimpert AK, Peavey LE, Friedlaender AS, Nowacek DP (2012) Humpback whale song and foraging behavior on an Antarctic feeding ground. PLoS ONE 7:8. https://doi.org/10.1371/journal.pone. 0051214

Straley J, O'Connell V, Liddle J, Thode A, Wild L, Behnken L, Falvey D, Lunsford C (2015) Southeast Alaska Sperm Whale Avoidance Project (SEASWAP): a successful collaboration among scientists and industry to study depredation in Alaskan waters. ICES J Mar Sci 72:1598-1609. https://doi.org/10.1093/icesjms/fsv090

Straley JM (1990) Fall and winter occurrence of humpback whales (Megaptera novaeangliae) in Southeastern Alaska. Rep Int Whal Comm Spec Iss 12:319-323

Straley JM, Moran JR, Boswell KM, Vollenweider JJ, Heintz RA, Quinn TJ, Witteveen BH, Rice SD (2018) Seasonal presence and potential influence of humpback whales on wintering Pacific herring populations in the Gulf of Alaska. Deep-Sea Res Top Stud Oceanogr 147:173-186. https://doi.org/10.1016/j.dsr2. 2017.08.008

Straley JM, Schorr GS, Thode AM, Calambokidis J, Lunsford CR, Chenoweth EM, O'Connell VM, Andrews RD (2014) Depredating sperm whales in the Gulf of Alaska: local habitat use and long distance movements across putative population boundaries. Endanger Species Res 24:125-135. https://doi.org/10.3354/esr00 595

Swartz SL, Taylor BL, Rugh DJ (2006) Gray whale Eschrichtius robustus population and stock identity. Mamm Rev 36:66-84. https:// doi.org/10.1111/j.1365-2907.2006.00082.x

Teerlink SF, von Ziegesar O, Straley JM, Quinn TJ, Matkin CO, Saulitis EL (2015) First time series of estimated humpback whale (Megaptera novaeangliae) abundance in Prince William Sound. Environ Ecol Stat 22:345-368. https://doi.org/10.1007/ s10651-014-0301-8

Thompson PO, Cummings WC, Ha SJ (1986) Sounds, source levels, and associated behavior of humpback whales, southeast Alaska. J Acoust Soc Am 80:735-740. https://doi.org/10.1121/1.393947

Thompson PO, Findley LT, Vidal O, Cummings WC (1996) Underwater sounds of blue whales, Balaenoptera musculus, in the Gulf of California, Mexico. Mar Mamm Sci 12:288-293. https://doi. org/10.1111/j.1748-7692.1996.tb00578.x

Thomsen F, Franck D, Ford JKB (2001) Characteristics of whistles from the acoustic repertoire of resident killer whales (Orcinus orca) off Vancouver Island, British Columbia. J Acoust Soc Am 109:1240-1246. https://doi.org/10.1121/1.1349537

Trudel M, Fisher J, Orsi JA, Morris JFT, Thiess ME, Sweeting RM, Hinton S, Fergusson EA, Welch DW (2009) Distribution and migration of juvenile Chinook salmon derived from coded wire tag recoveries along the continental shelf of western North America. Trans Am Fish Soc 138:1369-1391. https://doi.org/ 10.1577/t08-181.1

von Biela VR, Arimitsu ML, Piatt JF, Heflin B, Schoen SK, Trowbridge JL, Clawson CM (2019) Extreme reduction in nutritional value of a key forage fish during the Pacific marine heatwave of 2014-2016. Mar Ecol Prog Ser 613:171-182. https://doi.org/10. 3354/meps 12891

Vu ET, Clark C, Catelani K, Kellar NM, Calambokidis J (2015) Seasonal blubber testosterone concentrations of male humpback whales (Megaptera novaeangliae). Mar Mamm Sci 31:12581264. https://doi.org/10.1111/mms.12191
Vu ET, Risch D, Clark CW, Gaylord S, Hatch LT, Thompson MA, Wiley DN, Van Parijs SM (2012) Humpback whale song occurs extensively on feeding grounds in the western North Atlantic Ocean. Aquat Biol 14:175-183. https://doi.org/10.3354/ab00390

Wade PR, De Robertis A, Hough KR, Booth R, Kennedy A, LeDuc RG, Munger L, Napp J, Shelden KEW, Rankin S, Vasquez O, Wilson C (2011) Rare detections of North Pacific right whales in the Gulf of Alaska, with observations of their potential prey. Endanger Species Res 13:99-109. https://doi.org/10.3354/esr00 324

Wade PR, Kennedy A, LeDuc R, Barlow J, Carretta J, Shelden K, Perryman W, Pitman R, Robertson K, Rone B, Salinas JC, Zerbini A, Brownell RL, Clapham PJ (2011) The world's smallest whale population? Biol Lett 7:83-85. https://doi.org/10.1098/rsbl.2010. 0477

Waite JM, Dahlheim ME, Hobbs RC, Mizroch SA, von Ziegesar-Matkin O, Straley JM, Herman LM, Jacobsen J (1999) Evidence of a feeding aggregation of humpback whales (Megaptera novaeangliae) around Kodiak Island, Alaska. Mar Mamm Sci 15:210 220. https://doi.org/10.1111/j.1748-7692.1999.tb00792.x

Walker WA, Hanson MB (1999) Biological observations of Stejneger's beaked whale, Mesoplodon stejnegeri, from strandings on Adak Island, Alaska. Mar Mamm Sci 15:1314-1329. https://doi.org/ 10.1111/j.1748-7692.1999.tb00893.x

Walker WA, Mead JG, Brownell RL (2002) Diets of Baird's beaked whales, Berardius bairdii, in the southern sea of Okhotsk and off the pacific coast of Honshu, Japan. Mar Mamm Sci 18:902-919. https://doi.org/10.1111/j.1748-7692.2002.tb01081.x

Warren VE, Constantine R, Noad M, Garrigue C, Garland EC (2020) Migratory insights from singing humpback whales recorded around central New Zealand. R Soc Open Sci 7:15. https://doi. org/10.1098/rsos.201084

Watkins WA (1981) Activities and underwater sounds of fin whales. Sci Rep Whales Res Inst Tokyo: 83-118

Watkins WA, Schevill WE (1977) Sperm whale codas. J Acoust Soc Am 62:1485-1490. https://doi.org/10.1121/1.381678

Watkins WA, Tyack P, Moore KE, Bird JE (1987) The 20-Hz signals of finback whales (Balaenoptera physalus). J Acoust Soc Am 82:1901-1912. https://doi.org/10.1121/1.395685

Watwood SL, Miller PJO, Johnson M, Madsen PT, Tyack PL (2006) Deep-diving foraging behaviour of sperm whales (Physeter macrocephalus). J Anim Ecol 75:814-825. https://doi.org/10.1111/j. 1365-2656.2006.01101.x

Weirathmueller MJ, Stafford KM, Wilcock WSD, Hilmo RS, Dziak RP, Trehu AM (2017) Spatial and temporal trends in fin whale vocalizations recorded in the NE Pacific Ocean between 2003-2013. PLoS ONE 12:24. https://doi.org/10.1371/journal.pone.0186127

Weller DW, Klimek A, Bradford AL, Calambokidis J, Lang AR, Gisborne B, Burdin AM, Szaniszlo W, Urban J, Unzueta AG-G, Swartz S, Brownell RL Jr (2012) Movements of gray whales between the western and eastern North Pacific. Endanger Species Res 18:193-199. https://doi.org/10.3354/esr00447

Whitehead H (2002) Estimates of the current global population size and historical trajectory for sperm whales. Mar Ecol Prog Ser 242:295-304. https://doi.org/10.3354/meps242295

Whitehead H (2003) Sperm whales: social evolution in the ocean. The University of Chicago Press, Chicago

Whitney FA (2015) Anomalous winter winds decrease 2014 transition zone productivity in the NE Pacific. Geophys Res Lett 42:428 431. https://doi.org/10.1002/2014gl062634

Wiggins SM, Hildebrand JA (2007) High-frequency Acoustic Recording Package (HARP) for broad-band, long-term marine mammal monitoring. Symposium on Underwater Technology and Workshop on Scientific Use of Submarine Cables and Related Technologies, Vols 1 and 2: 594 
Wiggins SM, Oleson EM, McDonald MA, Hildebrand JA (2005) Blue whale (Baldenoptera musculus) diel call patterns offshore of southern California. Aquat Mamm 31:161-168. https://doi.org/ 10.1578/am.31.2.2005.161

Wild LA, Gabriele CM (2014) Putative contact calls made by humpback whales ( Megaptera novaeangliae ) in southeastern Alaska. Can Acoust 42:23-32

Wild LA, Mueter F, Witteveen BH, Straley JM (2020) Exploring variability in the diet of depredating sperm whales in the Gulf of Alaska through stable isotope analysis. R Soc Open Sci 7:17. https://doi.org/10.1098/rsos.191110

Witteveen BH (2008) Using stable isotopes to assess population structure and feeding ecology of North Pacific humpback whales (Megaptera novaeangliae). Dissertation, University of Central Florida

Wood SN (2011) Fast stable restricted maximum likelihood and marginal likelihood estimation of semiparametric generalized linear models. J R Stat Soc Ser B 73:3-36. https://doi.org/10.1111/j. 1467-9868.2010.00749.x

Yurk H, Barrett-Lennard L, Ford JKB, Matkin CO (2002) Cultural transmission within maternal lineages: vocal clans in resident killer whales in southern Alaska. Anim Behav 63:1103-1119. https://doi.org/10.1006/anbe.2002.3012
Zeh JM, Rekdahl ML, Rice AN, Clark CW, Rosenbaum HC (2020) Detections of humpback whale (Megaptera novaeangliae) vocalizations on an acoustic sensor in the New York Bight. Mar Mamm Sci. https://doi.org/10.1111/mms.12775

Zerbini AN, Waite JM, Durban JW, LeDuc R, Dahlheim ME, Wade PR (2007) Estimating abundance of killer whales in the nearshore waters of the Gulf of Alaska and Aleutian Islands using linetransect sampling. Mar Biol 150:1033-1045. https://doi.org/10. 1007/s00227-006-0347-8

Zerbini AN, Waite JM, Laake JL, Wade PR (2006) Abundance, trends and distribution of baleen whales off Western Alaska and the central Aleutian Islands. Deep-Sea Res Part I-Oceanogr Res Pap 53:1772-1790. https://doi.org/10.1016/j.dsr.2006.08.009

Zimmer WMX, Johnson MP, Madsen PT, Tyack PL (2005) Echolocation clicks of free-ranging Cuvier's beaked whales (Ziphius cavirostris). J Acoust Soc Am 117:3919-3927. https://doi.org/ $10.1121 / 1.1910225$

Publisher's Note Springer Nature remains neutral with regard to jurisdictional claims in published maps and institutional affiliations. 